Estuarine, Coastal and Shelf Science

January 2018, Volume 200, Pages 1-18

http://dx.doi.org/10.1016/j.ecss.2017.10.001

http://archimer.ifremer.fr/doc/00405/51649/

(c) 2017 Elsevier Ltd. All rights reserved.

\title{
Interplay between abiotic factors and species assemblages mediated by the ecosystem engineer Sabellaria alveolata (Annelida: Polychaeta)
}

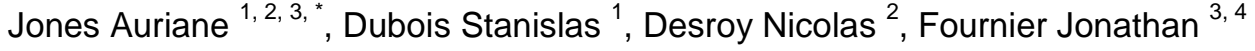

${ }^{1}$ IFREMER, Laboratoire Centre de Bretagne, DYNECO LEBCO, 29280 Plouzané, France

2 IFREMER, Laboratoire Environnement et Ressources Bretagne nord, 38 rue du Port Blanc, BP 80108, 35801 Dinard cedex, France

${ }^{3}$ CNRS, UMR 7208 BOREA, 61 rue Buffon, CP 53, 75231 Paris cedex 05, France

${ }^{4}$ MNHN, Station de Biologie Marine, BP 225, 29182 Concarneau cedex, France

* Corresponding author : Auriane Jones, email address : auriane.jones@ifremer.fr

\begin{abstract}
:
Sabellaria alveolata is a gregarious polychaete that uses sand particles to build three-dimensional structures known as reefs, fixed atop rocks or built on soft sediments. These structures are known to modify the local grain-size distribution and to host a highly diversified macrofauna, altered when the reef undergoes disturbances. The goal of this study was to investigate the different sedimentary and biological changes associated with the presence of a $S$. alveolata reef over two contrasting seasons (late winter and late summer), and how these changes were linked. Three different sediments were considered: the engineered sediment (the actual reef), the associated sediment (the soft sediment surrounding the reef structures) and a control soft sediment (i.e. no reef structures in close proximity). Univariate and multivariate comparisons of grain-size distribution, soft sediment characteristics (organic matter content, chlorophyll a, pheopigments and carbohydrate concentrations) and macrofauna were conducted between the different sediment types at both seasons and between the two seasons for each sediment type. A distance-based redundancy analyses (dbRDA) was used to investigate the link between the different environmental parameters and the macrofauna assemblages. Finally, we focused on a disturbance continuum of the engineered sediments proxied by an increase in the mud present in these sediments. The effects of a continuous and increasing disturbance on the associated fauna were investigated using pairwise beta diversity indices (Sørensen and Bray-Curtis dissimilarities and their decomposition into turnover and nestedness). Results showed a significant effect of the reef on the local sediment distribution (coarser sediments compared to the control) and on the benthic primary production (higher in the associated sediments). At both seasons, $S$. alveolata biomass and sediment principal mode were the environmental parameters which best differentiated the engineered, associated and control sediment assemblages. These two parameters are under the ecosystem engineer's influence stressing its importance in structuring benthic macrofauna. Furthermore, in late summer but not in late winter, presence/absence and abundance based beta diversity were positively correlated to our disturbance proxy (mud content) a tendency driven by a species replacement and a rise in the associated fauna density. Our first set of results highlight the importance of $S$. alveolata reefs as benthic primary production enhancers via their physical structure and their biological activity. The results
\end{abstract}


obtained using beta diversity indices emphasize the importance of recruitment in structuring the reef's macrofauna and - paradoxically - the ecological value of $S$. alveolata degraded forms as biodiversity and recruitment promoters.

\section{Graphical abstract}

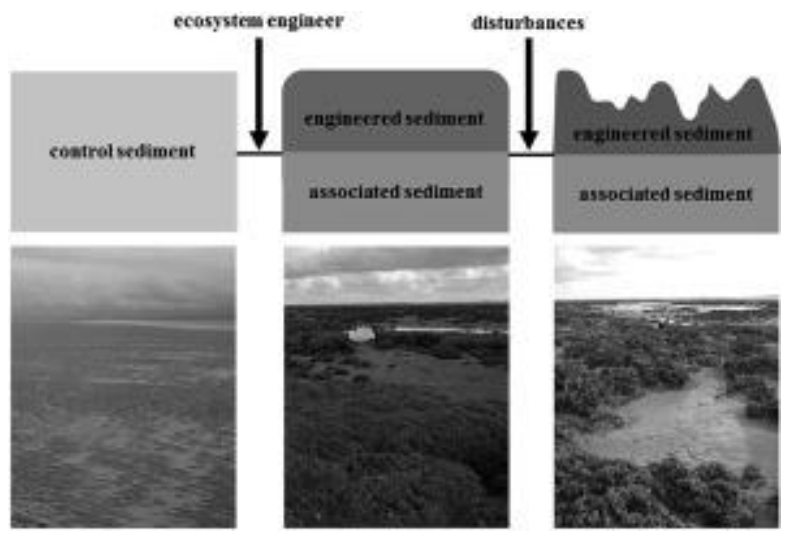

\section{Highlights}

- Sabellaria alveolata is a highly structuring ecosystem engineer via the reefs it creates and the abiotic and biotic modifications it induces. Benthic primary production is higher in the immediate vicinity of a Sabellaria alveolata reef. Sabellaria alveolata leads to the establishment of two distinct assemblages: one in the reefs and another in the soft sediment around them. An increasing disturbance of the reefs leads to a species turnover and a total abundance increase.

Keywords : Honeycomb worm, Macrobenthos, Benthic primary production, Habitat disturbance, Silt, Beta diversity, France Brittany, Mont Saint-Michel Bay

\section{Abbreviations}

$\begin{array}{ll}\text { MSMB } & \text { Mont Saint-Michel Bay } \\ \text { MPB } & \text { Microphytobenthos } \\ \text { TOM } & \text { Total organic matter } \\ \text { Chl a } & \text { Chlorophyll a } \\ \text { Pheo } & \text { Pheopigments } \\ \text { Ins } & \text { Insoluble carbohydrates } \\ \text { Sol } & \text { Soluble carbohydrates } \\ \text { dbRDA } & \text { Distance-based redundancy analysis } \\ \text { CPUE } & \text { Catch-per-unit-effort }\end{array}$




\section{Introduction}

Ecosystem engineers are organisms capable of modifying their local environment through their physical presence (i.e. autogenic engineers) and/or their biological activity (i.e. allogenic engineers), "directly or indirectly modulating the availability of resources to other species" (Jones et al., 1994). Ultimately, these species maintain, modify, create or even destroy habitats (Bouma et al., 2009; Jones et al., 1994). The abiotic modifications caused by ecosystem engineers can lead to facilitation for some organisms (Hacker and Gaines, 1997) and inhibition through negative species interaction for others (Bouma et al., 2009; Jones et al., 1997). Nonetheless, bioengineered habitats are often reported to host a more diverse species assemblage than the adjoining non-engineered habitats (Ataide et al., 2014; De Smet et al., 2015; Jones et al., 1997; Stachowicz, 2001). Physical ecosystem engineering appears to be particularly important where the environment is extreme (e.g. thermic, hydrodynamic and/or hydric stress), like in temperate intertidal areas (Bouma et al., 2009; Jones et al., 1997). Indeed, according to Jones et al. (1997, 1994), these extreme conditions might have favored the selection of "extended phenotype engineers" through enhanced survival of the engineer and the cohabiting fauna (Dawkins, 1982). These engineer species create complex habitats that reduce local pressures such as predation or thermal stress, whilst increasing biodiversity (Bouma et al., 2009). Ultimately, such favorable environmental changes can lead to an interesting paradox where "the spatial extent of the realized niche of a species can be larger than the spatial range predicted by the fundamental niche" as described by Bruno et al. (2003) and reported for mussels and barnacles in Ascophyllum nodosum canopies by Bertness et al. (1999).

Temperate coasts host a striking number of ecosystem engineering species, spanning from mollusks (for a review see Gutiérrez et al. (2003)) and polychaetes (e.g. Lanice conchilega (De Smet et al., 2015)) to canopyforming algae (e.g. Ascophyllum nodosum (Bertness et al., 1999)). Along the European coastline, a particular ecosystem engineer has the ability to build three-dimensional structures on top of sediments qualified as reefs (Holt et al., 1998). This species is a common gregarious tubiculous polychaete called Sabellaria alveolata (Linnaeus, 1767), a.k.a. the honeycomb worm. It generally lives in the intertidal zone from mid to low tide levels and can be found from Scotland and Ireland to Morocco (Muir et al., 2016). Sabellaria alveolata uses sand particles remobilized by waves and tidal action to build the tube in which it lives (Le Cam et al., 2011). Since the pelagic larvae are attracted by the L-dopa present in the organic cement produced by the adult worms for their tube-building activity, they will tend to settle on existing reefs (Pawlik, 1988; Wilson, 1968). This phenomenon coupled with favorable environmental conditions (i.e. grain-size structure, hydrodynamic processes, food availability and water temperature) can lead to the development of large biogenic reefs (Holt et al., 1998). These structures are commonly found on rocky substrata as veneers or hummocks where they rarely exceed $50 \mathrm{~cm}$ in 
height for a few tens of square meters but in some rare instances, they can be found in soft bottom areas where they can grow up to two meters in height and several hectares in size (Holt et al., 1998; Noernberg et al., 2010). The largest of these formations, which is also the largest biogenic habitat in Europe, is located in the Mont SaintMichel Bay (MSMB) in France (Desroy et al., 2011; Dubois et al., 2002).

The research around this species has mainly focused on its physiology (i.e. reproduction, fecundity, feeding mode) (Dubois et al., 2003, 2005, 2006a, 2009) and its tube building activity (Fournier et al., 2010; Le Cam et al., 2011). Other studies have looked into the ecology of reefs with a particular interest on the associated fauna (Dias and Paula, 2001; Porta and Nicoletti, 2009; Schlund et al., 2016) and factors influencing it such as the reef's different growth stages (Dubois et al., 2002), epibionts (Dubois et al., 2006b), human trampling (Plicanti et al., 2016) and ecological status (Desroy et al., 2011). A large part of these studies has focused on Sabellaria alveolata reefs on rocky substrata and not on soft sediment. Reefs developing on soft sediment are far less frequent along the European coast (i.e. MSMB and Bourgneuf Bay in France) (Holt et al., 1998). Nonetheless, they constitute exceptional locations composed of two distinct entities: the actual three-dimensional reef structures (engineered sediment), which is spatially discontinuous and the soft sediment present between the reef structures (associated sediment) (Desroy et al., 2011). Several kilometers separate them from the nearest rocky shore which signifies, in contrast to the veneer form of $S$. alveolata structures, complete isolation from most of the juvenile and adult fauna inhabiting these rocky shores. Furthermore, their physical borders are easy to visualize against the surrounding soft sediment. These sites give us the chance to study different components of S. alveolata's engineering effect (Passarelli et al., 2014; Wright et al., 2006). This engineering effect can be seen from both an environmental and a biological perspective by looking at how the ecosystem engineer modifies the local sedimentary characteristics and how the biodiversity changes between a control sediment, the associated and the engineered sediments. The control soft sediment represents the baseline or the unmodified state before the honeycomb worms start building reefs, hence representing a new structural state (Jones et al., 2010).

This biogenic habitat is not structurally homogenous, mainly due to multiple disturbances; direct natural disturbances such as storms and cold winters, direct anthropogenic disturbances such as trampling and indirect anthropogenic disturbances through shellfish farming and coastal engineering. These disturbances lead to a gradual modification of the reef visible through disaggregation, increasing fine sediments, decreasing ecosystem engineer density and increasing epibiont cover, causing a number of changes in the associated fauna (Dubois et al., 2006b, 2002; Plicanti et al., 2016). Modifications of the associated fauna have been investigated in several 
122

123

124

125

126

127

128

129

130

131

132

133

134

135

136

137

138

139

140

141

142

143

144

145

146

147

148

149

150

151

categorical ways but never along a disturbance continuum (Dubois et al., 2006b, 2002; Plicanti et al., 2016). To understand the changes in the associated fauna along this continuum, we chose to focus on the beta diversity seen as "the extent of change in community composition" as defined by Whittaker (1960) and on an abundancebased dissimilarity measurement using the Bray-Curtis dissimilarity. Analyzing beta diversity in a S. alveolata reef can help us understand the functioning of this biogenic habitat and give more relevant information to decision makers regarding conservation issues. First, taking into account the three previously defined sediment types (control, associated and engineered sediments), we tested in a categorical way, the following hypotheses: (1) the engineered sediment affects the different sedimentary characteristics of the associated sediment, especially grain-size, organic matter content and microphytobenthos and (2) the diversity and species composition of both the engineered and the associated sediments are different from the control sediment. We also looked into potential changes between late winter and late summer, regarding sediment composition and macrofauna assemblages for each sediment type. Then, using beta diversity and dissimilarity measurements, we tested the following hypothesis: an increasing disturbance of the engineered sediment promotes (1) beta diversity and more specifically species turnover and (2) abundance-based dissimilarity and more specifically abundance gradients.

\section{Materials and methods}

\subsection{Study area}

This study took place in the central part of the MSMB where the largest bioconstruction in Europe is located; the Sainte-Anne reef $\left(48^{\circ} 38^{\prime} 700 \mathrm{~N}\right.$ and $\left.1^{\circ} 40^{\prime} 100 \mathrm{~W}\right)$, built by the honeycomb worm Sabellaria alveolata (Desroy et al., 2011). This reef is situated in the lower intertidal zone (i.e. between the -2 and the $-4 \mathrm{~m}$ isobaths (Noernberg et al., 2010)), parallel to the coast and to the dominant tidal currents and also near important blue mussel (Mytilus edulis) cultures. In 2014, the maximal dimensions of the Sainte-Anne reef were $2.5 \mathrm{~km}$ in length for $1 \mathrm{~km}$ in width and the engineered sediment represented about 32 ha for about 128 ha of associated sediment (unpublished results). The area located in the central part of the bay and along the same isobath as the reef is characterized by medium to muddy sands (Bonnot-Courtois et al., 2009) and by a species poor "Macoma balthica community" (Dubois et al., 2002).

\subsection{Sampling design and laboratory analyses}

Two sampling areas were defined; the Sainte-Anne reef area and a control area. The reef area was composed of two sediment types, the engineered and the associated sediments (Fig. 1). The control area was a 
soft sediment zone located $1.5 \mathrm{~km}$ North-East of the reef area and on the same bathymetric level. It was characteristic of the medium to muddy sands found in this part of the bay (Bonnot-Courtois et al., 2009). Sampling took place over a two-day period in late winter (late February) and late summer (late September). These two seasons were chosen because they are highly contrasted environmentally (e.g. hydro-sedimentary features) and biologically (e.g. recruitment patterns, species turnover, growth rates). Indeed, winter is a period of low biological activity and high environmental pressures (cold temperatures, wind and storms) while late summer is a post-recruitment period with a higher biological activity (Arbach Leloup et al., 2008; Cugier et al., 2010). Hence, sampling at these two seasons helps us to have a more complete picture of the dynamics happening in our different study zones.

To investigate the effects of $S$. alveolata on diversity and species composition, we compared the macrofauna associated with the three different sediment types: the $S$. alveolata reefs, the sediments present around these structures and the control soft sediments. For each sediment type (i.e. engineered, associated and control sediment, Fig. 1), ten stations were sampled. Every engineered sediment station was paired with an associated sediment station, in order to investigate how the reef structures modify the adjoining soft sediment. The stations were at least $75 \mathrm{~m}$ apart and at each station, six samples separated by at least $5 \mathrm{~m}$ were randomly taken at low tide. The first three samples were done using a $18.5 \mathrm{~cm}$ side corer $\left(269 \mathrm{~cm}^{2}\right)$ to a depth of $15 \mathrm{~cm}$ (core samples). For engineered sediments, this depth corresponds to the layer where Sabellaria alveolata and more than $90 \%$ of all species live (Dubois et al., 2002). The other three samples were done using a $1 \mathrm{~m}^{2}$ quadrat in order to estimate the over dispersed macrofauna, mainly composed of bivalves and gastropods (quadrat samples). All engineered sediment samples (core and quadrat samples) were taken at least $1 \mathrm{~m}$ from the reef edge to avoid a known border effect on the macrofauna diversity (Gruet, 1972), while the associated sediment samples (core and quadrat samples) were taken at least $1 \mathrm{~m}$ away from the reef structures. The soft sediment core samples were sieved through a 1-mm square mesh on site while the engineered sediment core samples were taken back to the laboratory where they were broken apart under water and the fauna retained on a 1-mm square mesh was collected. Associated and control quadrat samples were done by sieving on site the first $5 \mathrm{~cm}$ of sediment through a 5-mm square mesh. For the engineered quadrat samples, we sampled by hand all the visible macrofauna located on the reef and inside the reef interstices. All core and quadrat samples were fixed in a 5\% formaldehyde solution, after which all the macrofauna was sorted, counted and identified to the species or genus level (except for nemerteans, oligochaetes and nematodes) and finally preserved in a 70\% ethanol solution. For each engineered sediment core sample, all the Sabellaria alveolata were weighted (total wet weight). 
To look at how the ecosystem engineer modifies its environment, we randomly collected three sediment

183 samples for grain-size distribution, total amount of organic matter (TOM), pigment concentration (i.e. chlorophyll $a$ and pheopigments) and total carbohydrate concentration (i.e. soluble and insoluble carbohydrates), at each associated and control sediment station. For the grain-size distribution, the first $5 \mathrm{~cm}$ of sediments were sampled using a small plastic core $\left(19 \mathrm{~cm}^{2}\right)$. For all the other sedimentary characteristics, only the first centimeter of sediment was sampled using a plastic petri dish $\left(57 \mathrm{~cm}^{2}\right)$. Additional samples were collected in order to characterize the sediments constituting the Sabellaria alveolata tubes as well as the sediments potentially trapped within the biogenic structure. These consisted in randomly collecting three small reef parts (about $8 \times 3 \mathrm{~cm}$ ) in each engineered sediment station. Sediment grain-size distribution was obtained by mechanical sieving using AFNOR calibrated sieves (from $25 \mathrm{~mm}$ to $63 \mu \mathrm{m}$ ) and granulometric parameters were estimated using the 'G2Sd' package in R v. 3.3.0 (Fournier et al., 2014). Prior to mechanical sieving, the engineered sediments were cautiously broken into their original elements, i.e. mostly bioclasts as evidenced in Le Cam et al. (2011). For all the other analyses, the sediments were first freeze-dried in order to work on dry matter. TOM was determined as the difference between the weight of freeze-dried sediment and the weight after 4 hours at $450^{\circ}$ (Aminot and Kerouel, 2004). Pigment concentrations ( $\mu \mathrm{g} \cdot \mathrm{g}^{-1}$ dry sediment) were estimated using the monochromatic technique (Lorenzen, 1967) described in Aminot and Kerouel (2004). The chlorophyll $a$ (Chl a) concentration was used as a proxy for microphytobenthos (MPB) biomass (Jeffrey et al., 1997) while pheopigments (Pheo) concentration gave us information about the amount of degraded photoautotrophs. Soluble carbohydrates (Sol) present in the sediment were extracted by hydrolysis $\left(100^{\circ} \mathrm{C}\right.$ for $\left.45 \mathrm{~min}\right)$, after which the pellets were treated with sulfuric acid $\left(\mathrm{H}_{2} \mathrm{SO}_{4}\right)$ and placed 4 hours at $100^{\circ} \mathrm{C}$ in order to obtain the insoluble carbohydrates (Ins). Sol and Ins concentrations ( $\mu \mathrm{g} \cdot \mathrm{g}^{-1}$ dry sediment) were then estimated by colorimetric phenol sulfuric dosage (Dubois et al., 1956). Sol were considered as being an important labile source of carbon for consumers living in the sediment such as bacteria and deposit-feeding invertebrates (Bellinger et al., 2009) while the insoluble carbohydrates to soluble carbohydrates ratio (Ins/Sol) was used as a proxy for the $\mathrm{C} / \mathrm{N}$ ratio and as a TOM degradation index (Delmas, 1983).

\subsection{Data analysis}

\subsubsection{Biological and environmental engineering effects}

Since macrofauna was sampled using two different techniques (cores and quadrats), densities of species were estimated using the catch-per-unit-effort (CPUE) method, i.e. the ratio between the total catch and the total amount of effort used to harvest the catch (Skalski et al., 2005). At one sampling location, when a species was 
only collected by core or quadrat, its density was estimated using the corresponding sampling surface. However, when a species was sampled by both methods, cumulated abundances were divided by the sum of each gear's CPUE. This estimation method was used for 17 species in late winter and 15 in late summer, taking into account all three sediment types. Species' densities were calculated using the formula:

$$
\operatorname{density}_{A}\left(\text { ind. } \mathrm{m}^{2}\right)=\frac{\left(\text { abundance }_{A q}+\text { abundance }_{A c}\right)}{\left(C P U E_{q}+C P U E_{C}\right)}
$$

where density $_{A}$ is species' A abundance per $\mathrm{m}^{2}$, abundance $_{A q}$ is species' A abundance using the quadrat, abundance $_{A c}$ is species' A abundance using the core, $C P U E_{q}$ is the quadrat's catch-per-unit-effort $\left(1 \mathrm{~m}^{2}\right)$ and $C P U E_{c}$ is the core's catch-per-unit-effort $\left(0.0269 \mathrm{~m}^{2}\right)$.

To assess the effect of Sabellaria alveolata on the associated macrofauna and validate our a priori grouping into engineered, associated and control sediments, Principal Coordinates Analysis (PCO) were performed for the late winter and late summer data sets. Analyses were performed on a Bray-Curtis similarity matrix calculated from log-transformed densities after $S$. alveolata was removed from the matrix, in order to take into account only the species associated with this sediment type. Indeed, because of its high abundance (i.e. on average, $63 \%$ of the total abundance), the single presence of $S$. alveolata would automatically cause a strong grouping of engineered sediment samples. Species present in only one sample (i.e. in less than $2 \%$ of all samples) were excluded from the initial matrix. To identify species typifying each sediment, species that correlated more than $60 \%$ with one of the first two axes (i.e. Spearman correlations) were plotted on each PCO. In parallel, a one-way univariate permutational ANOVA (permanova) was performed on the same species density matrices as for the PCOs, in order to evaluate if there was a significant difference in the species composition of each sediment type.

Finally, the macrofauna diversity of each replicate (core and associated quadrat) sampled in late winter and late summer, was assessed using Hill's indices; N0 (number of species), N1 (exp (H') where H' is the Shannon-Winner diversity $\left.\left(\log _{\mathrm{e}}\right)\right)$ and N2 (1/D where D is the Simpson's dominance index (Hill, 1973)) as recommended by Gray (2000) and the total macrofauna density. These indices inform how the total abundance is partitioned between the different species (Gray, 2000; Whittaker, 1972 for details). Densities calculated using the CPUE method and for $1 \mathrm{~m}^{2}$ as previously detailed, were used to calculate $\mathrm{N} 1$ and N2. For each replicate, N0 was calculated as the sum of the species richness recorded in the core and the species richness recorded in the associated quadrat. For N0, N1 and N2, S. alveolata was either kept or removed from the initial data in order to investigate how this species influences the partitioning of the associated fauna abundance. 
To test for significant differences between the three sediment types for the different grain size and macrofauna descriptors and because none of the descriptors fulfilled normality of distribution and homogeneity of variance, permanovas were performed, with sediment type considered as a fixed factor. We used Euclidian distance as a distance measure and ran 9999 permutations for each test. If the main test was significant, pairwise tests were performed. Effect of the presence of the engineered sediment on soft sediment environmental parameters (TOM, Chl $a$, Pheo and Ins/Sol) was investigated by comparing these parameters between associated and control sediments, also using permanovas. Prior to performing permanovas, we tested for homogeneity of dispersions using the PERMDISP PRIMER routine (Anderson et al., 2008). When raw data presented significantly different dispersions between the three sediment types $(\mathrm{p}<0.05)$, it was log transformed (in late winter: principal mode, TOM, Chl $a$, Pheo, macrofauna density with and without $S$. alveolata, N0 with and without S. alveolata and N2 with S. alveolata, in late summer: macrofauna density with and without S. alveolata, N0 with and without $S$. alveolata and N1 without $S$. alveolata). When log transformation did not lead to homogenous dispersions (in late winter: \% mud, \% sand and Sol, in late summer: TOM, Chl $a$, Sol, N1 and N2 calculated with $S$. alveolata), non-parametric statistical tests were performed (Kruskal-Wallis test for the granulometric and macrofauna parameters and Wilcoxon-Mann-Whitney for the other environmental parameters).

In order to evaluate if the different environmental and macrofauna parameters were significantly different between late winter and late summer for each sediment type, one-factor permanovas were performed, with season considered as a fixed factor. We chose to perform one-factor rather than two-factor univariate analysis of variance (in this case with sediment type and season as fixed factors), because we lacked replication inside each season for our different sediment types (Underwood, 1997). As previously mentioned, permanovas (9999 permutations) were used rather than t-tests because none of the investigated variables were normally distributed. Homogeneity of dispersions was also tested (PERMDISP) and data was transformed when necessary (square-root transformation for TOM in the associated sediments, log transformation for macrofauna density with S. alveolata in the control sediments and for macrofauna density without $S$. alveolata in the engineered sediments). The Permanovas, PERMDISP routines and PCOs were performed using the PRIMER v6 software with the PERMANOVA+ add-on (Anderson et al., 2008). Post-hoc Kruskal-Wallis tests were performed with the 'kruskalmc' function from the 'pgirmess' package (Giraudoux, 2016) using R version 3.3.0 (R Core Team, 2016).

\subsubsection{Linking environmental and biological engineering effects}


The relationship between the environmental characteristics and the macrofauna present in the three

271

272

273 sediment types was investigated using distance-based linear models (DistLM). In line with Legendre and Anderson (1999) and McArdle and Anderson (2001), DistLM models were coupled to a distance-based redundancy analysis (dbRDA) to define the best fitted model in a multi-dimensional space in a way similar to a constrained PCO. DistLM models were built using the Bayesian Information Criterion (BIC) to identify "good" models and the 'best' procedure to select the variables according to the BIC. Prior to the DistLM and dbRDA analysis, the environmental parameters were displayed using Draftsman plots and the ones presenting an important skewness were transformed to approach normality (Anderson et al., 2008). If two predictor variables were strongly correlated $\left(\mathrm{r}^{2}>0.80\right)$, one of them was removed from the analysis in order to avoid multicollinearity (Dormann et al., 2013). Except for the grain-size data, environmental parameters used to characterize an engineered sediment sample were the same as for its corresponding associated sediment sample. For late winter, the final predictor data set contained the $\%$ sand, Pheo (both square-root transformed), $\%$ mud, TOM, $S$. alveolata biomass (all three fourth-root transformed), principal mode and Ins/Sol (both log transformed). For late summer, the final predictor data set was the same as for late winter, except the $\%$ sand which was removed (absolute correlation with \% mud > 0.8). S. alveolata biomass was used rather than abundance because this parameter provides more information about ecosystem functioning (Cardinale et al., 2013). S. alveolata biomass was considered as a predictor variable since it physically modifies its environment and it was consequently removed from the macrofauna data set. The DistLM models and dbRDA analysis were performed using the PRIMER v6 software with the PERMANOVA+ add-on (Anderson et al., 2008).

\subsubsection{Disturbances and biological engineering effect}

At its climax, a $S$. alveolata reef is formed by $100 \%$ honeycomb worm tubes, leaving virtually no space for infaunal organisms. When natural or anthropogenic disturbances (e.g. storms, trampling) physically damage the reef, tubes are destroyed, freeing up space. This new available space can be filled either with other organisms such as the oyster Magallana gigas (formerly known as Crassostrea gigas) or by fine particles. Fine particles accumulate from suspended sediments, or from the feces and pseudofeces of $S$. alveolata and other bivalves (biodeposition) (Dubois et al., 2006b). In either case, this fine sediment can end up trapped inside the $S$. alveolata reefs. Consequently, the increased deposition of mud inside the engineered sediments is the result of several different and often concomitant disturbances. Fine sediment deposition has previously been recognized as a significant disturbance to stream macroinvertebrates (Mathers et al., 2017) and benthic habitats (Balata et al., 2007; Mateos-Molina et al., 2015; Miller et al., 2002). Similarly, we chose to consider mud content as a 
proxy for disturbance. This proxy was also chosen because it is independent from Sabellaria alveolata

301 population dynamics and physiological state. Finally, using the mud content makes the two seasons readily comparable.

Beta diversity was calculated using pairwise multivariate distances since they are independent of sample size and regional diversity (gamma diversity) allowing accurate potential comparisons among regions (Bennett and Gilbert, 2016). We chose to use the presence/absence based indices presented by Baselga (2010) in order to partition total beta diversity, expressed by Sørensen dissimilarity $\left(\beta_{\text {sor }}\right)$, into the turnover $\left(\beta_{\text {sim }}\right)$ and nestedness $\left(\beta_{\text {nes }}\right)$ components. In this case, $\beta_{\text {sor }}=\beta_{\text {sim }}+\beta_{\text {nes. }}$. Under conditions of equal species richness, $\beta_{\text {sor }}=\beta_{\text {sim }}$ and $\beta_{\text {nes }}=$ 0 , while under conditions of unequal species richness, $\beta_{\text {sim }}$ and $\beta_{\text {nes }}$ vary between 0 and $\beta_{\text {sor }}$. Sørensen dissimilarity varies between 0 and 1 , with 0 indicating that two samples have identical species list and 1 indicating no common species (Baselga, 2010). For $\beta_{\text {sim }}, 0$ indicates complete nestedness, and a maximal value of 1 can be found if in one of the two considered samples, there are no species recorded and in the other, the number of species is maximal (Koleff et al., 2003). To have a complementary vision of how disturbance affected the associated fauna abundance, the abundance-based dissimilarity (Bray-Curtis dissimilarity, $\mathrm{d}_{\mathrm{BC}}$ ) was also partitioned into balanced changes in abundance $\left(\mathrm{d}_{\mathrm{BC}-\text { bal }}\right)$ and abundance gradients $\left(\mathrm{d}_{\mathrm{BC}-\text { gra }}\right)$, which are closely related to turnover and nestedness components respectively (Baselga, 2013). These indices were computed after removing S. alveolata from the presence/absence and density matrices. They were calculated using the pairwise measures in order to have the beta diversity and the dissimilarities for each pair of samples (i.e. 435 pairs). Then, using Euclidian distance, all the mud content pairwise differences were calculated. Finally, using the different pairwise measures, we performed Mantel tests (9999 permutations) for late winter and late summer data, to test the null hypothesis of no relationship between the mud content distance matrix and each beta diversity matrix. A p-value below 0.05 indicates a significant correlation between the two investigated distance matrices, with the sign of the r-value indicating if the two matrices are positively or negatively associated. The beta diversity indices were computed using the 'beta.pair' function, and the Bray-Curtis dissimilarity indices using the 'bray.part' function, both from the 'betapart' R package (Baselga, 2013). The Mantel tests were performed using the 'mantel.rtest' function from the 'ade4' R package (Dray and Dufour, 2007).

To test the link between the macrofaunal assemblages based on their respective beta diversity and dissimilarity indices and the disturbance parameter (i.e. mud content), non-metric multidimensional scaling ordinations (nMDS) were successively performed for each index ( $\beta_{\text {sor }}, \beta_{\text {sim }}, \beta_{\text {nes }}, \mathrm{d}_{\mathrm{BC}}, \mathrm{d}_{\mathrm{BC} \text {-bal }}$ and $\left.\mathrm{d}_{\mathrm{BC} \text {-gra }}\right)$ and at each sampling period (late winter and late summer) using the 'metaMDS' function of the 'MASS' R package 
(Venables and Ripley, 2002). Then, the 'envfit' function ('vegan' R package) was used to test if the mud content was significantly correlated with each ordination (Oksanen et al., 2016). When a correlation was significant, the mud contents were fitted and plotted on the given nMDS using the 'ordisurf' function of the 'vegan' R package (Oksanen et al., 2016). All these analyses were performed using R version 3.3.0 (R Core Team, 2016).

\section{Results}

\subsection{Environmental engineering effect}

Mean values of grain-size distribution parameters measured within each sediment type are reported in Table 1a. Analyses revealed significant differences between the sediment types for all tested metrics in late winter $(\mathrm{p}<0.001)$ and for all but one in late summer (mud content). At both periods, there was a strong engineering effect on the principal mode marked by a significantly coarser sediment in the engineered and associated sediments than in the control sediments (Table 1a). In late winter, the sorting index $S_{0}$ was significantly lower in the engineered and associated sediments than in the control and mud content was significantly lower in the associated sediments than in the other two sediment types. Finally, the sand content was significantly higher in the engineered sediment relative to the other sediment types. In late summer, associated sediments had a higher sorting index than the engineered sediments and one comparable to the control sediments. Although associated sediments were also characterized by a higher mud content in late summer compared to late winter (permanova: $\mathrm{p}=0.0051$ ), no significant difference was observed between the three sediment types. For all grain-size parameters, the control sediments showed no significant changes between late winter and late summer (permanova: $\mathrm{p}($ principal mode $)=0.23, \mathrm{p}\left(\mathrm{S}_{0}\right)=0.60, \mathrm{p}($ mud $)=0.37$ and $\mathrm{p}($ sand $\left.)=0.42\right)$. The pattern was similar for the engineered sediments (permanova: $\mathrm{p}$ (principal mode) $=0.059, \mathrm{p}\left(\mathrm{S}_{0}\right)=0.78$, $\mathrm{p}($ mud $)=0.78$ and $\mathrm{p}($ sand $)=0.39)$. The associated sediments showed significant changes in their grain-size distribution between late winter and late summer. In late winter, they were much more homogenous than in late summer (Table 1) and they became significantly muddier between the two sampling campaigns (permanova: $\mathrm{p}=$ 0.0051 ) leading to a significant decrease in the principal mode (permanova $=0.025$ ).

The comparison of sedimentary parameters revealed a strong engineering effect at both periods regarding TOM, Chl $a$ and Sol (Table 1b, p < 0.005). In both seasons, TOM was consistently twice as high in the engineered environment than in the control zone. Organic matter content also showed a significant decrease between late winter and late summer in the reef zone (permanova: $p=0.029$ ) and no significant temporal change in the control sediments (permanova: $\mathrm{p}=0.29$ ). Similarly, Chl $a$ concentration was ten times higher in the soft 
sediments adjacent to the engineered structures than in the control and did not display any significant temporal changes in either the control (permanova: $p=0.29$ ) or the associated sediments (permanova: $p=0.72$ ). Sol concentration was also consistently four times higher in the reef environment than in the control and displayed a temporal stability similar to the $\mathrm{Chl} a$ (permanova: $\mathrm{p}($ control $)=0.87$ and $\mathrm{p}($ associated $)=0.82)$. In late winter, the Pheo concentration was significantly higher in the control than in the associated sediments while in late summer, there was no significant difference. In both sediment types, Pheo concentrations did not show significant changes between the two sampling campaigns (permanova: $p($ control $)=0.10$ and $p($ associated $)=0.11)$. Finally, Ins/Sol was not significantly different between associated and control sediments in late winter and late summer, and was significantly higher in late winter compared to late summer for the control sediments (permanova: $\mathrm{p}=0.0001$ ). This temporal pattern was not detected in the associated sediments (permanova: $p=0.28$ ) probably because of the important variability in late winter (Table 1).

\subsection{Biological engineering effect}

In late winter, 9244 organisms belonging to 121 different taxa were sampled in the cores and 8478 organisms belonging to 26 different taxa were sampled with the quadrats (see the Appendix for a complete list of species). Comparatively, in late summer more organisms and taxa were sampled with the cores (23463 organisms/125 taxa) while fewer organisms and more taxa were sampled with the quadrats (4677 organisms/30 taxa). For all sediment types, total species richness was consistently higher in late summer than in late winter but this difference was significant only for the control and engineered sediments (permanova: $\mathrm{p}(\mathrm{control})=0.039$, $\mathrm{p}($ associated $)=0.071$ and $\mathrm{p}($ engineered $)=0.0001)$

PCOs and one-way permanovas performed on density matrices indicated that the three sediment types significantly differed $(\mathrm{p}<0.05)$ in their associated fauna at both sampling periods, confirming our $a$ priori sediment type grouping (Fig. 2 and Fig. 3). PCO axis 1 explained in late winter and late summer, respectively 26.1 and $30.3 \%$ of the total variation present in the resemblance matrix and clearly separated the engineered samples from the control samples. PCO axis 2 explained in late winter and late summer, respectively 14.6 and $14.8 \%$ of the total variation and discriminated the engineered and control samples from the associated samples. In both seasons, engineered samples were highly clustered compared to the more scattered associated and control sediments samples. In late winter, the control and associated sediments were well separated while there was a small overlap between the associated and engineered sediments (Fig. 2). In late summer, there was an overlap between the associated and control sediments (Fig. 3). This overlap was mostly due to bivalves like Limecola balthica or Cerastoderma edule and to the polychaete Nephtys hombergii (Fig. 3 and Appendix). Finally, 
engineered sediments were characterized by a much greater number of species correlated at more than $60 \%$ with each PCO axis (11 in late winter and 17 in late summer) than the associated ( 3 in late winter and 1 in late summer) and the control sediments ( 3 in late winter and 6 in late summer).

Mean macrofauna diversity indices and densities were calculated within each sediment type and for each sampling campaign (Table 2a and b). At the sediment type scale, one-way permanovas showed significant differences between engineered sediments on the one hand and associated and control sediments on the other, for all the diversity measurements and densities at both periods. There were two exceptions regarding N1 and N2 calculated in late summer with $S$. alveolata taken into account. In these cases, there were no significant differences between the three sediment types. When $S$. alveolata was taken into account, total macrofauna density was 20 times higher in the engineered sediments at both periods. This difference was maintained even after S. alveolata was removed from the data set but it was reduced to an average 5-fold difference. The engineered sediment was also home to significantly more species (mean species richness N0) than the associated and control sediments and this, whatever the situation.

Regarding macrofauna density, $\mathrm{N} 1$ and $\mathrm{N} 2$, associated and control sediments presented similar temporal patterns when comparing late winter and late summer. Their respective macrofauna density increased significantly between the two campaigns (permanova: $\mathrm{p}($ control $)=0.023$ and $\mathrm{p}($ associated $)=0.018$ ) while $\mathrm{N} 1$ and $\mathrm{N} 2$ showed non-significant differences (permanova: $\mathrm{p}($ control-N1) $=0.15, \mathrm{p}($ control-N2) $=0.25$, $\mathrm{p}($ associated-N1 $)=0.83$ and $\mathrm{p}($ associated-N2 $)=0.53)$. Between late winter and late summer, the engineered sediments presented a significant increase in the total macrofauna density (permanova: p(density with $S$. alveolata $)=0.0001$ ) only driven by a significant increase in the associated fauna density (permanova: $\mathrm{p}($ density without $S$. alveolata $)=0.0001$ and $\mathrm{p}(S$. alveolata density $)=0.54)$. They also showed a significant increase in the case of $\mathrm{N} 1$ and $\mathrm{N} 2$ calculated with $S$. alveolata (permanova: $\mathrm{p}(\mathrm{N} 1)=0.0007$ and $\mathrm{p}(\mathrm{N} 2)=0.0001$ ), a change which was not significant once the engineer species was removed (permanova: $\mathrm{p}(\mathrm{N} 1)=0.089$ and $\mathrm{p}(\mathrm{N} 2)=0.73$ ).

\subsection{Linking environmental and biological engineering effects}

DistLM and dbRDA analysis were performed in late winter (Fig. 4a) and late summer (Fig. 4b) with $S$. alveolata biomass considered as an environmental parameter. In both seasons, S. alveolata biomass was the parameter which best explained the relationship between environmental parameters and macrofauna assemblages ( $18.0 \%$ in late winter and $24.8 \%$ in late summer). In late winter, the most parsimonious model, explaining $33.6 \%$ of the total variation in species assemblages, was defined by (1) Sabellaria biomass (square-root transformed, $18.0 \%$ ), (2) principal mode (log transformed, 13.2\%) and (3) total organic matter content (fourth-root 
transformed, $10.7 \%$, Fig. 4). The first two axes explained $91.6 \%$ of the fitted variation and $30.7 \%$ of the total variation. Species assemblage were structured according to two gradients. The first was driven by $S$. alveolata, and separated engineered sediments from the two other types. The second was driven by the sediment principal mode and the total organic matter content and separated the associated from the control sediments (Fig. 4a). In late summer, the most parsimonious model explained $40.7 \%$ of the total variation in species assemblages. It was defined by the same first two variables as for late winter: Sabellaria biomass (square-root transformed, 24.8\%) and principal mode (log transformed, $16.9 \%$ ). The third selected variable differed from late winter since it was the mud content (fourth-root transformed) and it explained only a very small part of the total variation $(0.079 \%)$. The first two axes explained $87.5 \%$ of the fitted variation and $35.6 \%$ of the total variation. Again, species assemblages were structured according to two gradients but they did not separate the different sediment types as clearly as in late winter. S. alveolata still defined the first gradient and clearly separated the engineered sediments from the two soft sediments. The opposition between the principal mode and the mud content defined the second gradient. Along this gradient, the distinction associated/control sediments was not well defined. Indeed, there were three associated sediment samples characterized by high mud contents and isolated from the rest of the associated sediment samples (Fig. 4b).

\subsection{Disturbances and biological engineering effect}

Consistent mean values in late winter (10\%) and late summer (9.59\%), confirm the choice of the mud content as a suitable 'disturbance parameter' (Table 1a). Indeed, these values did not significantly vary between the two contrasted seasons we sampled (permanova: $\mathrm{p}=0.78$ ). In contrast, the mean $S$. alveolata density almost doubled between late winter $\left(7682 \pm 3312\right.$ ind.m $\left.\mathrm{m}^{-2}\right)$ and late summer $\left(12844 \pm 14262\right.$ ind. $\left.\mathrm{m}^{-2}\right)$, with a very high summer variability, leading to no significant change (permanova: $\mathrm{p}=0.54$ ). Oppositely, the mean $S$. alveolata biomass by surface unit significantly decreased between late winter $\left(646 \pm 317 \mathrm{~g}\right.$. $\left.\mathrm{m}^{-2}\right)$ and late summer $(318 \pm$ 211 g. $\left.\mathrm{m}^{-2}\right)$ (permanova: $\left.\mathrm{p}=0.0001\right)$

Mantel tests performed between the mud content distance matrix and the different beta diversity matrices showed a clear temporal difference between late winter and late summer. The tests were not significant when performed using the late winter data sets $(\mathrm{p}>0.05$, Table 3$)$, while they revealed a significant and positive correlation between the mud content distance matrix and $\beta_{\text {sor }}(\mathrm{p}<0.001, \mathrm{r}=0.24), \beta_{\text {sim }}(\mathrm{p}=0.0066, \mathrm{r}=0.15), \mathrm{d}_{\mathrm{BC}}$ $(\mathrm{p}<0.001, \mathrm{r}=0.38)$ and $\mathrm{d}_{\mathrm{BC} \text {-gra }}(\mathrm{p}<0.001, \mathrm{r}=0.29)$ (Table 3$)$ using the late summer data sets. These results indicate that in late winter, an increase in mud content, used as a proxy for disturbance, does not lead to beta diversity changes but in late summer, it leads to (1) an increase in beta diversity driven by a species replacement 
and (2) an increase in abundance based dissimilarity driven by an abundance gradient. Ordination plots of similarities (nMDS) of macrofaunal assemblages based on $\beta_{\text {sor }}, \beta_{\text {sim }}, \beta_{\text {nes }}, \mathrm{d}_{\mathrm{BC}}, \mathrm{d}_{\mathrm{BC} \text {-bal }}$ and $\mathrm{d}_{\mathrm{BC} \text {-gra }}$ indices were performed in late winter and late summer (Fig. 5 and 6). In late winter, the correlation between the mud content and the different nMDS plots was significant for $\beta_{\text {sor }}(\mathrm{p}=0.008), \beta_{\text {nes }}(\mathrm{p}=0.023), \mathrm{d}_{\mathrm{BC}}(\mathrm{p}=0.019)$ and $\mathrm{d}_{\mathrm{BC}-\text {-gra }}(\mathrm{p}=$ 0.027). The mud content explained $30.67 \%$ of the ordination based on $\beta_{\text {sor }}$ and $24.54 \%$ of the ordination based on $\beta_{\text {nes }}$. Similarly, $26.93 \%$ and $24.51 \%$ of the ordination based on $d_{B C}$ and $d_{B C-\text { gra }}$ respectively where explained by the mud content. In late summer, the correlation between the mud content and the different nMDS plots was significant and much higher for all the indices; $\beta_{\text {sor }}(p=0.001), \beta_{\text {nes }}(p=0.036), \beta_{\text {sim }}(p=0.001), d_{B C}(p=0.001)$, $d_{B C-\text {-gra }}(p=0.002)$ and $d_{B C-b a l}(p=0.006)$. Indeed, the mud content explained over $50 \%$ of the ordination based on

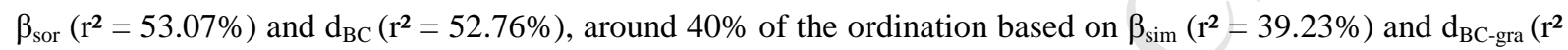
$=41.33 \%)$, and between 20 and $30 \%$ of $\beta_{\text {nes }}\left(\mathrm{r}^{2}=21.25 \%\right)$ and $\mathrm{d}_{\mathrm{BC}-\mathrm{bal}}\left(\mathrm{r}^{2}=29.56 \%\right)$. When the correlation was significant, the fitted mud contents were plotted on the corresponding nMDS plots (Fig. 5 and 6). The correlation between the disturbance proxy and the different nMDS plots showed a pattern similar to the one revealed by the late summer Mantel test, with beta diversity changes mainly driven by a species turnover and an abundance gradient.

\section{Discussion}

\subsection{Engineered structures cause grain-size distribution changes}

Environmental engineering effects are composed of two types of changes, structural and abiotic changes, structural changes being caused by ecosystem engineers and inducing abiotic changes (Jones et al., 2010). S. alveolata is capable of biologically modifying soft sediments by selectively gluing together bioclastic sand particles, in order to build its tube (Fournier et al., 2010). This leads to the transformation of an initial soft sediment into a three-dimensional hard substratum with a long lasting resistance to physical loading via the secreted organic cement (Le Cam et al., 2011). Sabellaria alveolata can therefore be considered as a "structural engineer" according to Berke (2010). Structural changes caused by physical ecosystem engineers result in a variation in the distribution of fluid and solid material termed abiotic changes (Jones et al., 2010). In the case of S. alveolata, a direct abiotic engineering effect observable through the engineered sediments and an indirect one, observable through the associated sediments, were detected. Engineered and associated sediments presented, at both sampling periods, a coarser texture than the control sediments, confirming the impact Sabellariidae polychaetes have on the local sediment's texture by selecting sand particles of a specific size to build their tubes 
(Phragmatopoma caudata $(=$ P. lapidosa) $($ Gram, 1968; Kirtley and Tanner, 1968; Main and Nelson, 1988),

Sabellaria vulgaris (Wells, 1970), Sabellaria nanella (Bremec et al., 2013)). Ultimately, these bioconstructing Sabellariidae species create reefs characterized by a grain-size distribution different from the local soft sediments. The case of the associated sediments raises the question of the definition of a reef habitat. In Europe, "reefs" are recognized as a marine habitat to be protected and are listed under Annex I of the EC Habitats Directive (Council Directive EEC/92/43 on the Conservation of Natural Habitats and of Wild Fauna and Flora) under the designation of Special Areas of Conservation (SACs). They are defined as "submarine or exposed at low tide, rocky substrates and biogenic concretions". In the light of our findings, we can very well consider the engineered and the associated sediments as the same sediment but under two different forms, a consolidated (engineered sediments) and an unconsolidated form (associated sediments). Hence, we propose to widen the definition of a "reef" to include the non-engineered sediments under its direct influence.

The main difference between the engineered and associated sediments concerns their mud content. At both seasons, the engineered sediments have a mean mud content around $10 \%$, as previously observed by Le Cam et al. (2011). Sabellaria wilsoni veneers have also been reported to present consistent silt and clay contents across two contrasting seasons (rainy and dry seasons in Ataide et al., 2014) indicating that Sabellariidae polychaetes build new habitats presenting stable sedimentary conditions. The mud present in the engineered sediments is located in small cracks and crevices protected from the main hydrodynamic processes (i.e. winter storms, tidal currents and swell). Conversely, the associated sediments are characterized by a steep and significant increase in mud content between winter (2\%) and summer (21\%). As shown by Caline et al. (1988) for the Sainte-Anne reef (MSMB), localized mud depositions are linked to hydrodynamic and associated hydrosedimentary processes induced by the presence of the reef itself and of the mussel farms (bouchots) in front of the reef (McKindsey et al., 2011). These mud depositions are observed behind reef structures important enough to act as physical barriers (Caline et al., 1988), where they are generally superficial and consequently easily eroded by strong wave action, limiting their presence in winter.

\subsection{Engineered structures enhance benthic primary production and potentially microbial activity}

As reported by Jones et al. (2010), abiotic changes induced by physical engineering activity can themselves cause biotic changes. Our results clearly show that at both seasons, associated sediments have a higher organic matter content compared with the control sediments. At both seasons, high levels of organic matter were associated with high chlorophyll $a$ concentrations, indicating that part of the organic matter present in the associated sediments is the consequence of MPB development. The high benthic primary production 
promoted by the Sainte-Anne reef, compared to a generally lower benthic production in the MSMB as measured by Davoult et al. (2008) and Migné et al. (2009), confirms its important biotic engineering effect. Similar results were found for the invading intertidal reef-forming polychaete Ficopomatus enigmaticus (Bruschetti et al., 2011), for shallow oyster reefs (Crassostrea virgina, Newell et al., 2002) and for intertidal mussel beds (Engel et al., 2017). According to Berke (2010), "structural engineers operate through similar processes and have similar types of effects". Consequently, the creation of benthic primary production hotspots by reef-building structural engineers could be a general property of these marine species. Nonetheless, this phenomenon was observed at the scale of the largest and probably oldest S. alveolata reef in Europe (Audouin and Milne-Edwards, 1832) and the study by Engel et al. (2017) highlighted the importance of the size and age of the bioconstruction in promoting local benthic microalgae. Hence, further studies are needed to confirm the general role of S. alveolata reefs as "biological power stations" (Engel et al., 2017).

Furthermore, the high chlorophyll $a$ concentrations measured in late winter and late summer indicate that $S$. alveolata reefs promote an important benthic primary production all year round, that could be a relevant food source for deposit- (Kanaya et al., 2008) and suspension-feeders (Lefebvre et al., 2009) through resuspension processes (Hylleberg, 1975; Ubertini et al., 2015). In the associated sediments, MPB often grows on small accumulations of pure mud and is consequently easily eroded and available to consumers. Such benthic primary production may have a trophic importance during the winter months (Lefebvre et al., 2009), when the phytoplankton production is typically low (Arbach Leloup et al., 2008; Cugier et al., 2010). Filter feeding mollusks are known to stimulate MPB growth (Engel et al., 2017; Newell et al., 2002) via inorganic nutrient release (i.e. carbon, nitrogen and phosphorus (van Broekhoven et al., 2014)) and bacterial remineralization of their biodeposits (van Broekhoven et al., 2015). Similarly, S. alveolata produces large amounts of feces and pseudofeces visible on the sediment (Dubois et al., 2005), that could favor MPB growth. Primary production could also be enhanced by the presence of other suspension-feeders living in the engineered sediments, such as Magallana gigas, which can reach densities of 100 ind. $\mathrm{m}^{-2}$ as measured in the disturbed engineered sediments using the quadrats. As already observed in Ficopomatus enigmaticus reefs (Bruschetti et al., 2011), S. alveolata reefs probably increase the bentho-pelagic coupling by linking pelagic organic matter to the benthic compartment via their suspension-feeding activity and biodeposition.

In late winter and late summer, associated sediments had consistently higher soluble carbohydrate concentrations than the control sediments. Carbohydrates are the components of the mucus coating the pseudofeces produced by S. alveolata and other suspension-feeders (van Broekhoven et al., 2015). Hence, when 
540

541

542

543

544

545

546

547

548

549

550

551

552

553

554

555

556

557

558

559

560

561

562

563

564

565

566

567

568

569

these pseudofeces are deposited on the associated sediments, it could increase their concentration in soluble carbohydrates. Soluble carbohydrates also compose the extracellular polymeric substances produced by benthic diatoms (Bellinger et al., 2009) and are an important source of organic carbon, rapidly consumed by heterotrophic microorganisms present in the sediment (Bhaskar and Bhosle, 2005; Goto et al., 2001). Consequently, S. alveolata presence could support all year round an important bacterial activity through the soluble carbohydrates excreted by the diatoms and present in the mucus coating the biodeposits. This organic carbon can either be used by the bacteria for their growth (bacterial biomass production) or be remineralized (bacterial respiration) as showed by Hubas et al. (2006). In the first case, the bacteria can be a source of food for infaunal organisms such as nematodes and become an important trophic link in structuring energy fluxes in the community (Pascal et al., 2009, 2008). In the second case, the bacteria release inorganic nutrients such as carbon (Jiao et al., 2010), which can then be used by photoautotrophs present in the sediment (e.g. diatoms) or in the water column (e.g. phytoplankton) further maintaining the local primary production.

Furthermore, according to Delmas (1983), an insoluble/soluble carbohydrate ratio (Ins/Sol) ranging between 6 and 8 indicates a low degradation rate of the organic matter, while a ratio varying between 10 and 30 reflects a high degradation rate. Delmas (1983) also suggests using the Ins/Sol ratio as a proxy for the C/N ratio. Mean Ins/Sol ratios were not significantly different between the associated and control sediments with values around 8.6 in late winter, and 6.0 in late summer, indicating that $S$. alveolata does not affect the organic matter degradation rate in soft sediments; it is consistently of good quality and weakly degraded. Nonetheless, in late summer, the organic matter present in the control and associated sediments appears less degraded and more easily incorporable in the food web than in late winter, probably in response to a higher biological activity of photoautotrophs and bacterial communities (Hubas et al., 2006).

\subsection{Engineered structures create an original macrofauna assemblage linked to the sedimentary changes}

In addition to promoting the local benthic production, S. alveolata strongly modifies the macrofauna assemblages present in the engineered and associated sediments compared to the control sediments and this difference is present at both sampling seasons. Consequently, S. alveolata engineers two original species assemblages, one associated with the actual bioconstructions and the other associated with the sediments surrounding these structures. In late winter and late summer, the environmental parameter primarily responsible for macrofauna differences between the three sediment types is the ecosystem engineer via its biomass. Studies on other ecosystem engineers have demonstrated a similar structuring effect of the engineer on the macrofauna, for example via Haploops nirae density in subtidal mats (Rigolet et al., 2014) and Lanice conchilega density in 
570

571

572

573

574

575

576

577

578

579

580

581

582

583

584

585

586

587

588

589

590

591

592

593

594

595

596

597

598

intertidal beds (De Smet et al., 2014). The benthic macrofauna is secondarily structured by the principal mode and the organic matter content of the sediments, two environmental parameters reported to structure soft sediment macrofauna communities in a large diversity of sites such as the intertidal flats of the Schelde estuary (Ysebaert and Herman, 2002) and over multiple spatial scales in Portuguese transitional water systems (Veiga et al., 2016). In our case, these two parameters are influenced by S. alveolata, indicating the importance of this engineer species in structuring the local benthic macrofauna.

Structural diversity analyses indicate that assemblages present in the associated and control sediments are similarly structured in late winter and late summer. Dominant species are mainly polychaetes (e.g. Goniadella bobrezkii) and mollusks species (e.g. Crepidula fornicata) in the associated sediments and the mollusks Limecola balthica and Cerastoderma edule in the control sediments, with a consortium of less abundant species. Furthermore, the benthic fauna present in the associated sediments appears as a combination of species living in the two other sediment types, enriched by polychaete species such as Glycera tridactyla, Protodorvillea kefersteini and Saccocirrus papillocercus. These three polychaete species are either carnivorescavengers or surface deposit-feeders, with important movement capacities, key biological traits in organic matter rich and variable environments (Rigolet et al., 2014) like the associated sediments. The overlapping observed between the control and associated sediments is much more pronounced in late summer, after the recruitment period (Thorin et al., 2001) and is caused by a few species (e.g. Cerastoderma edule, Limecola balthica or Nephtys hombergii). Cerastoderma edule recruitment and settlement of macrozoobenthos larvae is known to be enhanced coastward of mussel beds due to a decrease in hydrodynamic forces caused by these bioengineered habitats (Commito et al., 2005; Donadi et al., 2014, 2013). Similarly, S. alveolata reefs act as natural breakwaters limiting hydrodynamic energy, which could lead to an enhanced recruitment of macrobenthic species like Cerastoderma edule and Limecola balthica. This phenomenon is a lot less visible in winter maybe indicating that these species do not survive the variable environmental conditions characterizing the associated sediments or the winter temperatures. Indeed, locals repeatedly come to the Sainte-Anne reef to dig up bivalves like cockles (Cerastoderma edule) and Japanese carpet shells (Ruditapes philippinarum) enhancing small-scale spatial heterogeneity and potentially leading to changes in the macrofauna of the associated sediments (Watson et al., 2017). We also recorded inside the associated sediments some species generally present in the engineered sediments, like P. cultrifera or G. vulgaris. This can be caused by the presence of broken reef parts in the associated sediments, because of the variable sedimentary preferences of 
some species (e.g. G. vulgaris) or because of the use of the associated sediments by some species to move between reef patches (e.g. Perinereis cultrifera).

Species richness and associated macrofauna density were always highest in the engineered sediments than in the two soft sediments, stressing $S$. alveolata's role in enhancing local biodiversity and abundance. Our results confirm previous studies on S. alveolata reefs (Dias and Paula, 2001; Dubois et al., 2002; Holt et al., 1998) and agree with a large body of literature reporting positive effects of tubiculous polychaete species (De Smet et al., 2015), reef-building polychaetes (McQuaid and Griffiths, 2014) and bivalves (Gutiérrez et al., 2003; Lejart and Hily, 2011; Norling and Kautsky, 2007) on species richness and associated fauna abundances. Intertidal engineers like $S$. alveolata create new complex habitats that reduce pressures such as thermal and hydric stress and increase the number of primary producers (i.e. MPB and ulva), potentially extending trophic niches and overall leading to a biodiversity increase (Bouma et al., 2009; Jones et al., 1997; Stachowicz, 2001). New environmental conditions created by $S$. alveolata also lead to the paradox mentioned by Bertness et al. (1999), and facilitate the colonization of intertidal zones by subtidal species, like the polychaete Spirobranchus lamarcki or the gastropod Crepidula fornicata.

Structural diversity indices calculated for the engineered sediments (considering S. alveolata) and the beta diversity analysis both reveal a change between late winter and late summer in how the macrofauna is structured. In late winter, $\mathrm{N} 1$ and $\mathrm{N} 2$ are both significantly lower than in the two other sediment types while in late summer, macrofauna density in the engineered sediments is distributed similarly than in the associated and control sediments. Consequently, during winter S. alveolata dominates more strongly the engineered sediments than the dominant species present in the associated and control sediments, a result similar to the Haploops nirae habitats in summer (Rigolet et al., 2014). Differently, in late summer S. alveolata does not affect the community structure in a different way than other abundant species do in the associated (Crepidula fornicata, Cirriformia tentaculata, Mediomastus fragilis, Goniadella bobrezkii) and control sediments (Cerastoderma edule, Limecola balthica, Lanice conchilega, Malmegrenia arenicolae and Nepthys spp.). Regarding beta diversity, it significantly increases along the disturbance gradient in late summer but not in late winter. These observed contrasts between the two seasons can have two causes, probably acting in synergy: a low S. alveolata recruitment and an important recruitment of associated species. This last argument was also suggested by MateoRamirez et al. (2015) to explain the increase in decapod abundance associated with Posidonia oceanica meadows, between winter-spring and summer-autumn. In the MSMB, the recruitment success of S. alveolata is known to be strongly year-to-year variable depending on the synchrony between favorable environmental 
conditions (tidal and meteorological conditions) and main reproductive periods (Ayata et al., 2009), and 2015 seemed to be a year characterized by low settlement rates (pers. obs.). A weak S. alveolata recruitment leads to a decrease in spatial competition between the engineer and other macrofauna species favoring recruitment of associated species. Indeed, between winter and summer, many other benthic species recruit in the MSMB (Thorin et al., 2001) and biogenic habitats like Mytilus edulis and Crepidula spp. beds, are known to favor recruitment of pelagic larvae (Berke, 2010) by affecting boundary-layer flow (Eckman, 1983). Consequently, a low S. alveolata recruitment associated with the upraised position of the reef in a soft bottom environment and the absence of neighboring hard substratum, one exception being the off-bottom mussel farms, lead to an important recruitment of benthic larvae to the Sainte-Anne reef. The hard nature of the engineered sediments can also act as either a support for egg capsules (e.g. Nucella lapillus) or an attractant for pelagic larvae of rocky shore species like Gibbula umbilicalis or Eulalia viridis (Kingsford et al., 2002). When S. alveolata is excluded, $\mathrm{N} 1$ and N2 values are systematically higher in the engineered sediments, a pattern unaffected by season. Sabellaria alveolata associated macrofauna shows a structuration similar to Lanice conchilega intertidal beds (De Smet et al., 2015) when compared to non-engineered sediments. De Smet et al. (2015) also recorded the lack of a temporal effect on N1 and N2. Consequently, despite its strong dominance, S. alveolata creates a speciesrich habitat where individuals are overall equitably distributed between taxa.

\subsection{Engineered sediment disturbance and mechanisms linked to beta diversity changes}

S. alveolata reefs are subject to various disturbances causing changes in species richness and composition (Dubois et al., 2006b, 2002; Plicanti et al., 2016) but not in diversity indices (Dubois et al., 2002). According to Clarke and Gorley (2006), diversity indices are unable to detect subtle changes in complex communities like S. alveolata reefs. Hence, using beta diversity and abundance-based dissimilarity along a continuum can help us detect these changes and better understand how disturbances affect the macrofauna associated with the reef. The Mantel tests indicate that in summer the beta diversity increases along the disturbance gradient, driven by a species turnover and an increase in species abundances. Differently, the multidimensional ordinations based on Sørensen and Bray-Curtis dissimilarities, are at both seasons significantly correlated with the mud content. Consequently, mud appears as a driver of beta diversity changes all year round but its importance increases between late winter and late summer.

All year round, mud can act directly as an environmental filter for some benthic species present inside the reef and lead to a beta diversity increase (Baselga, 2010). Indeed, mud could play the same environmental filter role in the engineered sediments as it does in soft sediments (Anderson, 2008; Ysebaert and Herman, 
2002). Disturbances to the reef also increase its structural complexity and frees space creating new microhabitats. The increase in the engineered sediment's complexity and heterogeneity, linked to our disturbance proxy, lead to an increase in species richness and beta diversity (Ellingsen and Gray, 2002) by mechanisms like the provision of refuges from predation and physical stressors (Margiotta et al., 2016). Finally, disturbed engineered sediments are more fragmented than their undisturbed counterparts. The important spatial continuity characterizing platform reefs (Dubois et al., 2002) and engineered sediments in "good ecological status" (Desroy et al., 2011) lead to an increase in the dispersal potential of mobile predators like decapods (e.g. Carcinus maenas), gastropods (e.g. Ocenebra erinaceus) and errant polychaetes (e.g. Eulalia viridis). In an experimental microbial landscape, dispersal had a negative effect on local community, metacommunity and landscape beta diversity (Sørensen dissimilarity) mainly because of predation by generalist predators (Cadotte and Fukami, 2005). Consequently, all year round, negative biotic interactions are probably acting in synergy with environmental sorting and habitat complexity to shape the observed beta diversity changes.

Between late winter and late summer, many benthic species recruit. The recruitment of benthic species to soft bottom sediments is known to be under the influence of biotic factors like organic content and food supply (Snelgrove and Butman, 1994). In spring-summer, the mud present in the disturbed engineered sediments is probably richer in organic matter, presenting a better quality compared to winter, as suggested by the associated sediment results. Multiple facts go in this direction. First, part of the spring phytoplankton bloom is known to sediment, potentially enriching the mud in fresh organic matter (Cugier et al., 2010). Second, during spring and summer green algae develop on the reef (Dubois et al., 2006b) enriching the mud in fresh detritus. Finally, in spring and summer S. alveolata and other suspension-feeders (Magallana gigas and Mytilus cf. galloprovincialis) increase their metabolic rates (Gillooly et al., 2001) and consequently produce more feces and pseudofeces, which could further enrich the mud in organic matter. In the end, changes in abiotic factors (topographic complexity, spatial competition and presence of microdepositional environments (small gapes in the reef filled with fine sediments, Snelgrove et al., 1993)) associated with changes in trophic factors (trophic competition, trophic cues (green algae and MPB present on and around the tubes - pers. obs.)) probably act in synergy and cause the recruitment of a richer and different assemblage of species in the disturbed reef parts compared to the undisturbed ones. Indeed, our results show an increase settlement of opportunistic and depositfeeding species, like Capitella capitata, Cirriformia tentaculata, Parathelepus collaris and Tharyx killariensis, and of species presenting a high affinity for mud (Corophium volutator) in the more disturbed reefs. In the same time, the release in spatial and trophic competition linked to a decrease in the engineer density, favors the 
settlement of suspension-feeding species like Magallana gigas and Porcellana platycheles. In late summer, some of these species are present in very high densities like P. platycheles (up to 9000 ind. $\mathrm{m}^{-2}$ ), Achelia spp. (up to 7000 ind. $\mathrm{m}^{-2}$ ) or Corophium volutator (up to 5000 ind. $\mathrm{m}^{-2}$ ), while the others are less abundant. In the end, the interplay between recruitment and the engineered sediments dynamics seem responsible for the observed species turnover and abundance increase along the disturbance gradient. In addition, other factors linked to an increasing disturbance, like a higher oyster cover (Magallana gigas) probably also structure the associated fauna as shown by Dubois et al. (2006). Indeed, oyster shells provide a suitable substratum for many sessile species and are known to enhance species richness and abundance (Lejart and Hily, 2011).

Finally, the late winter and late summer multidimensional ordinations also show that at both seasons, mud rates above $10-12 \%$ induce a homogenization of the species composition, congruently with results of Balata et al. (2007). They reported that in subtidal rocky reefs structured by the coralline algae Lithophyllum spp., the sedimentation "reduced the dissimilarity between assemblages overriding the influence of inclination of the substratum on beta diversity". The packing of samples ordinated by $\mathrm{d}_{\mathrm{BC}}$ is also greater for mud contents above $12 \%$ indicating that high mud contents not only streamline the species composition but also their absolute abundances.

\section{Conclusion}

Our results illustrate the need to protect a system in its integrity and not just parts of it. In our case, future conservation plans should consider $S$. alveolata reefs and associated sediments as an ecological entity. These habitats are in theory targeted by the European Union's Habitats Directive 92/43/EEC (habitat type 1170 'Reef') but in practice, very few reefs are protected. In the Sainte-Anne reef, a local legislation prohibits the harvesting of bivalves in the associated soft sediments (e.g. Ruditapes philippinarum) but not on the engineered sediments (e.g. Magallana gigas) increasing anthropogenic disturbances to the reef. In this context, prohibiting such practices until interactions between $S$. alveolata and $M$. gigas, particularly regarding benthic primary production and trophic competition, are clearly elucidated, should be considered.

Furthermore, the biogenic habitat created by $S$. alveolata is home to an original species assemblage presenting a high richness and density all year round, a case similar to many other structural engineers (Berke, 2010; Jones et al., 1994). These habitats are subject to numerous environmental and anthropogenic disturbances leading to changes in their physical structuration and complexity. In the MSMB, these changes are associated with the establishment of mud inside the engineered sediments, the increase in microhabitat availability and 
more diversified food sources. All year round, these differences act as environmental filters for post-recruits and juveniles. During the summer recruitment period, these differences act as cues for settling larva, leading to an enhanced recruitment inside the more disturbed reefs. In the end, during the spring-summer period, an increasing disturbance leads to an increase in species richness, a change in the species present in the engineered sediments (turnover) and to higher abundances (abundance gradient). This species turnover pleads for a recognition of the ecological value the "degraded" S. alveolata reefs have, as biodiversity and recruitment promoters.

Finally, our results are in contradiction with a study reporting that increasing disturbances to mussel beds increased patchiness and in the end reduced the diversity of the associated macrofauna (Díaz et al., 2015), highlighting the variable response fauna associated to structural engineers can have to disturbances. These different results also stress the importance of spatial and temporal scale on evaluating the impact disturbances have on biodiversity, as reported by Lepori and Hjerdt (2006) for aquatic systems.

\section{Acknowledgments}

This project was funded by an EC2CO DRIL (CNRS) grant. A. G. J. was supported by the "Laboratoire d'Excellence" LabexMER (ANR-10-LABX-19) and co-funded by a grant from the French government under the program "Investissements d'Avenir" and by a Région Bretagne/Ifremer PhD grant. Our funding source had no involvement in the different phases of this study. We wish to thank all the people that helped us on the field (François Gaudin, Patrick Le Mao, Anthony Sturbois, Daniel Gerla, Julien Chevé, Françoise Dagault, Claire Rollet, René Taraud and of course Pompon) and in the lab (Ségolène Jambut, Anne Verdurmen, Célia Bellengier, Julia Penot and Angelica Navarro). Daniel Delmas provided technical help for sediment analyses. We also thank Thibault Androuin, Martin Marzloff and Rémi Prudhomme for their comments on an earlier draft of the manuscript and Amelia Curd for the English editing.

\section{References}

Aminot, A., Kerouel, R., 2004. Hydrologie des écosystèmes marins. Paramètres et analyses, Ifremer. ed. ISBN 2-84433-133-5.

Anderson, M., Gorley, R.N., Clarke, R.K., 2008. Permanova+ for Primer: Guide to Software and Statistical Methods.

Anderson, M.J., 2008. Animal-sediment relationships re-visited: Characterising species' distributions along an environmental gradient using canonical analysis and quantile regression splines. Journal of Experimental Marine Biology and Ecology, Marine ecology: A tribute to the life and work of John S. Gray 366, 16-27. doi:10.1016/j.jembe.2008.07.006

Arbach Leloup, F., Desroy, N., Le Mao, P., Pauly, D., Le Pape, O., 2008. Interactions between a natural food web, shellfish farming and exotic species: The case of the Bay of Mont Saint Michel (France). Estuarine, Coastal and Shelf Science 76, 111-120. doi:10.1016/j.ecss.2007.06.011 
Ataide, M.B., Venekey, V., Filho, J.S.R., Santos, P.J.P. dos, 2014. Sandy reefs of Sabellaria wilsoni (Polychaeta: Sabellariidae) as ecosystem engineers for meiofauna in the Amazon coastal region, Brazil. Marine Biodiversity 44, 403-413. doi:10.1007/s12526-014-0248-x

Audouin, J.V., Milne-Edwards, H., 1832. Recherches pour servir à l'histoire naturelle du littoral de la France, ou Recueil de mémoires sur l'anatomie, la physiologie, la classification et les mœurs des animaux des nos côtes: Voyage à Granville, aux îles Chausey et à Saint Malo. Crochard.

Ayata, S.-D., Ellien, C., Dumas, F., Dubois, S., Thiebaut, E., 2009. Modelling larval dispersal and settlement of the reef-building polychaete Sabellaria alveolata: Role of hydroclimatic processes on the sustainability of biogenic reefs. Continental Shelf Research 29, 1605-1623. doi:10.1016/j.csr.2009.05.002

Balata, D., Piazzi, L., Benedetti-Cecchi, L., 2007. Sediment disturbance and loss of beta diversity on subtidal rocky reefs. Ecology 88, 2455-2461. doi:10.1890/07-0053.1

Baselga, A., 2013. Separating the two components of abundance-based dissimilarity: balanced changes in abundance vs. abundance gradients. Methods in Ecology and Evolution 4, 552-557. doi:10.1111/2041210X.12029

Baselga, A., 2010. Partitioning the turnover and nestedness components of beta diversity. Global Ecology and Biogeography 19, 134-143. doi:10.1111/j.1466-8238.2009.00490.x

Bellinger, B.J., Underwood, G.J.C., Ziegler, S.E., Gretz, M.R., 2009. Significance of diatom-derived polymers in carbon flow dynamics within estuarine biofilms determined through isotopic enrichment. Aquatic Microbial Ecology 55, 169-187. doi:10.3354/ame01287

Bennett, J.R., Gilbert, B., 2016. Contrasting beta diversity among regions: how do classical and multivariate approaches compare? Global Ecology and Biogeography 25, 368-377. doi:10.1111/geb.12413

Berke, S.K., 2010. Functional groups of ecosystem engineers: a proposed classification with comments on current issues. Integr. Comp. Biol. 50, 147-157. doi:10.1093/icb/icq077

Bertness, M.D., Leonard, G.H., Levine, J.M., Schmidt, P.R., Ingraham, A.O., 1999. Testing the relative contribution of positive and negative interactions in rocky intertidal communities. Ecology 80, 27112726. doi:10.1890/0012-9658(1999)080[2711:TTRCOP]2.0.CO;2

Bhaskar, P.V., Bhosle, N.B., 2005. Microbial extracellular polymeric substances in marine biogeochemical processes. Current Science 88, 45-53.

Bonnot-Courtois, C., Maze, J.P., Le Vot, M., Augris, C., Ehrhold, A., Simplet, L., Blanchard, M., 2009. Carte morpho-sédimentaire de la baie du Mont Saint-Michel (Ille-et-Vilaine et Manche) échelle 1/25 000, Quae. ed. Ifremer.

Bouma, T.J., Olenin, S., Reise, K., Ysebaert, T., 2009. Ecosystem engineering and biodiversity in coastal sediments: posing hypotheses. Helgoland Marine Research 63, 95-106. doi:10.1007/s10152-009-0146$\mathrm{y}$

Bremec, C., Carcedo, C., Piccolo, M.C., Santos, E. dos, Fiori, S., 2013. Sabellaria nanella (Sabellariidae): from solitary subtidal to intertidal reef-building worm at Monte Hermoso, Argentina $\left(39^{\circ} \mathrm{S}\right.$, south-west Atlantic). Journal of the Marine Biological Association of the United Kingdom 93, 81-86. doi:10.1017/S0025315412000550

Bruno, J.F., Stachowicz, J.J., Bertness, M.D., 2003. Incorporating facilitation into ecological theory. Trends in Ecology and Evolution 18, 119-125. doi:10.1016/S0169-5347(02)00045-9

Bruschetti, M., Bazterrica, C., Fanjul, E., Luppi, T., Iribarne, O., 2011. Effect of biodeposition of an invasive polychaete on organic matter content and productivity of the sediment in a coastal lagoon. Journal of Sea Research 66, 20-28. doi:10.1016/j.seares.2011.04.007

Cadotte, M.W., Fukami, T., 2005. Dispersal, spatial scale, and species diversity in a hierarchically structured experimental landscape. Ecology Letters 8, 548-557. doi:10.1111/j.1461-0248.2005.00750.x

Caline, B., Gruet, Y., Legendre, C., 1988. Les récifs à annélides (Hermelles) en Baie du Mont Saint-Michel: écologie, géomorphologie, sédimentologie, implications géologiques. BRGM, Orléans.

Cardinale, B.J., Gross, K., Fritschie, K., Flombaum, P., Fox, J.W., Rixen, C., van Ruijven, J., Reich, P.B., Scherer-Lorenzen, M., Wilsey, B.J., 2013. Biodiversity simultaneously enhances the production and stability of community biomass, but the effects are independent. Ecology 94, 1697-1707. doi:10.1890/12-1334.1

Clarke, K.R., Gorley, R.N., 2006. PRIMER V6: user manual-tutorial. PRIMER-E, Plymouth.

Commito, J.A., Celano, E.A., Celico, H.J., Como, S., Johnson, C.P., 2005. Mussels matter: postlarval dispersal dynamics altered by a spatially complex ecosystem engineer. Journal of Experimental Marine Biology and Ecology 316, 133-147. doi:10.1016/j.jembe.2004.10.010

Cugier, P., Struski, C., Blanchard, M., Mazurié, J., Pouvreau, S., Olivier, F., Trigui, J.R., Thiébaut, E., 2010. Assessing the role of benthic filter feeders on phytoplankton production in a shellfish farming site: Mont Saint Michel Bay, France. Journal of Marine Systems 82, 21-34. doi:10.1016/j.jmarsys.2010.02.013 
Davoult, D., Migné, A., Créach, A., Gévaert, F., Hubas, C., Spilmont, N., Boucher, G., 2008. Spatio-temporal variability of intertidal benthic primary production and respiration in the western part of the Mont SaintMichel Bay (Western English Channel, France). Hydrobiologia 620, 163-172. doi:10.1007/s10750008-9626-3

Dawkins, R., 1982. The extended phenotype. Oxford University Press, Oxford, England.

De Smet, B., D’Hondt, A.-S., Verhelst, P., Fournier, J., Godet, L., Desroy, N., Rabaut, M., Vincx, M., Vanaverbeke, J., 2015. Biogenic reefs affect multiple components of intertidal soft-bottom benthic assemblages: the Lanice conchilega case study. Estuarine, Coastal and Shelf Science 152, 44-55. doi:10.1016/j.ecss.2014.11.002

Delmas, D., 1983. Les glucides et l'évolution de la matière organique dans les sédiments marins. Oceanologica Acta 6, 157-165.

Desroy, N., Dubois, S.F., Fournier, J., Ricquiers, L., Le Mao, P., Guerin, L., Gerla, D., Rougerie, M., Legendre, A., 2011. The conservation status of Sabellaria alveolata (L.) (Polychaeta: Sabellariidae) reefs in the Bay of Mont-Saint-Michel. Aquatic Conservation: Marine and Freshwater Ecosystems 21, 462-471. doi:10.1002/aqc.1206

Dias, A.S., Paula, J., 2001. Associated fauna of Sabellaria alveolata colonies on the central coast of Portugal. Journal of the Marine Biological Association of the United Kingdom 81, 169-170. doi:10.1017/S0025315401003538

Díaz, E.R., Erlandsson, J., Westerbom, M., Kraufvelin, P., 2015. Depth-related spatial patterns of sublittoral blue mussel beds and their associated macrofaunal diversity revealed by geostatistical analyses. Marine Ecology Progress Series 540, 121-134. doi:10.3354/meps11461

Donadi, S., van der Heide, T., van der Zee, E.M., Eklöf, J.S., de Koppel, J. van, Weerman, E.J., Piersma, T., Olff, H., Eriksson, B.K., 2013. Cross-habitat interactions among bivalve species control community structure on intertidal flats. Ecology 94, 489-498. doi:10.1890/12-0048.1

Donadi, S., van der Zee, E.M., van der Heide, T., Weerman, E.J., Piersma, T., van de Koppel, J., Olff, H., Bartelds, M., van Gerwen, I., Eriksson, B.K., 2014. The bivalve loop: Intra-specific facilitation in burrowing cockles through habitat modification. Journal of Experimental Marine Biology and Ecology 461, 44-52. doi:10.1016/j.jembe.2014.07.019

Dormann, C.F., Elith, J., Bacher, S., Buchmann, C., Carl, G., Carré, G., Marquéz, J.R.G., Gruber, B., Lafourcade, B., Leitão, P.J., Münkemüller, T., McClean, C., Osborne, P.E., Reineking, B., Schröder, B., Skidmore, A.K., Zurell, D., Lautenbach, S., 2013. Collinearity: a review of methods to deal with it and a simulation study evaluating their performance. Ecography 36, 27-46. doi:10.1111/j.16000587.2012.07348.x

Dray, S., Dufour, A.-B., 2007. The ade4 package: implementing the duality diagram for ecologists. Journal of statistical software 22, 1-20.

Dubois, M., Gilles, K.A., Hamilton, J.K., Rebers, P.A., Smith, F., 1956. Colorimetric method for determination of sugars and related substances. Analytical Chemistry 28, 350-356. doi:10.1021/ac60111a017

Dubois, S., Barillé, L., Cognie, B., 2009. Feeding response of the polychaete Sabellaria alveolata (Sabellariidae) to changes in seston concentration. Journal of Experimental Marine Biology and Ecology 376, 94-101. doi:10.1016/j.jembe.2009.06.017

Dubois, S., Barillé, L., Cognie, B., Beninger, P., 2006a. Feeding mechanism of the polychaete Sabellaria alveolata revisited:: reply to Riisgard \& Nielsen (2006). Marine Ecology Progress Series 328, 307-311.

Dubois, S., Barillé, L., Cognie, B., Beninger, P.G., 2005. Particle capture and processing mechanisms in Sabellaria alveolata (Polychaeta: Sabellariidae). Marine Ecology Progress Series 301, 159-171. doi:10.3354/meps301159

Dubois, S., Barillé, L., Retière, C., 2003. Efficiency of particle retention and clearance rate in the polychaete Sabellaria alveolata L. Comptes Rendus Biologies 326, 413-421. doi:10.1016/S1631-0691(03)00124-0

Dubois, S., Commito, J.A., Olivier, F., Retière, C., 2006b. Effects of epibionts on Sabellaria alveolata (L.) biogenic reefs and their associated fauna in the Bay of Mont Saint-Michel. Estuarine, Coastal and Shelf Science 68, 635-646. doi:10.1016/j.ecss.2006.03.010

Dubois, S., Retière, C., Olivier, F., 2002. Biodiversity associated with Sabellaria alveolata (Polychaeta: Sabellariidae) reefs: effects of human disturbances. Journal of the Marine Biological Association of the United Kingdom 82, 817-826. doi:10.1017/S0025315402006185

Eckman, J.E., 1983. Hydrodynamic processes affecting benthic recruitment. Limnol. Oceanogr. 28, $241-257$. doi:10.4319/lo.1983.28.2.0241

Ellingsen, K., Gray, J. s., 2002. Spatial patterns of benthic diversity: is there a latitudinal gradient along the Norwegian continental shelf? Journal of Animal Ecology 71, 373-389. doi:10.1046/j.13652656.2002.00606.x 
Engel, F.G., Alegria, J., Andriana, R., Donadi, S., Gusmao, J.B., van Leeuwe, M.A., Matthiessen, B., Eriksson, B.K., 2017. Mussel beds are biological power stations on intertidal flats. Estuarine, Coastal and Shelf Science 191, 21-27. doi:10.1016/j.ecss.2017.04.003

Fournier, J., Etienne, S., Le Cam, J.-B., 2010. Inter- and intraspecific variability in the chemical composition of the mineral phase of cements from several tube-building polychaetes. Geobios 43, 191-200. doi:10.1016/j.geobios.2009.10.004

Fournier, J., Gallon, R.K., Paris, R., 2014. G2Sd: a new R package for the statistical analysis of unconsolidated sediments. Géomorphologie: relief, processus, environnement 20, 73-78. doi:10.4000/geomorphologie.10513

Gillooly, J.F., Brown, J.H., West, G.B., Savage, V.M., Charnov, E.L., 2001. Effects of size and temperature on metabolic rate. Science 293, 2248-2251. doi:10.1126/science.1061967

Giraudoux, P., 2016. Pgirmess: Data Analysis in Ecology.

Goto, N., Mitamura, O., Terai, H., 2001. Biodegradation of photosynthetically produced extracellular organic carbon from intertidal benthic algae. Journal of Experimental Marine Biology and Ecology 257, 73-86. doi:10.1016/S0022-0981(00)00329-4

Gram, R., 1968. A Florida Sabellariidae reef and its effect on sediment distribution. Journal of Sedimentary Research 38, 863-868. doi:10.1306/74D71A96-2B21-11D7-8648000102C1865D

Gray, J.S., 2000. The measurement of marine species diversity, with an application to the benthic fauna of the Norwegian continental shelf. Journal of Experimental Marine Biology and Ecology 250, 23-49. doi:10.1016/S0022-0981(00)00178-7

Gruet, Y., 1972. Aspects morphologiques et dynamiques de constructions de l'Annelide polychete Sabellaria alveolata (Linne). Revue des Travaux de l'Institut des Pêches Maritimes 36, 131-161.

Gutiérrez, J.L., Jones, C.G., Strayer, D.L., Iribarne, O.O., 2003. Mollusks as ecosystem engineers: the role of shell production in aquatic habitats. Oikos 101, 79-90. doi:10.1034/j.1600-0706.2003.12322.x

Hacker, S.D., Gaines, S.D., 1997. Some implications of direct positive interactions for community species diversity. Ecology 78, 1990-2003. doi:10.1890/0012-9658(1997)078[1990:SIODPI]2.0.CO;2

Hill, M.O., 1973. Diversity and evenness: a unifying notation and its consequences. Ecology 54, 427-432. doi:10.2307/1934352

Holt, T.J., Rees, E.I., Hawkins, S.J., Seed, R., 1998. Biogenic reefs. An overview of dynamic and sensitivity characteristics for conservation management of marine SACs. Scottish Association for Marine Science, UK Marine SACs Project.

Hubas, C., Lamy, D., Artigas, L.F., Davoult, D., 2006. Seasonal variability of intertidal bacterial metabolism and growth efficiency in an exposed sandy beach during low tide. Marine Biology 151, 41-52. doi:10.1007/s00227-006-0446-6

Hylleberg, J., 1975. Selective feeding by Abarenicola pacifica with notes on Abarenicola vagabunda and a concept of gardening in lugworms. Ophelia 14, 113-137. doi:10.1080/00785236.1975.10421972

Jeffrey, S.W., Mantoura, R.F.C., Wright, S.W., 1997. Phytoplankton pigments in oceanography: guidelines to modern methods. UNESCO Publishing.

Jiao, N., Herndl, G.J., Hansell, D.A., Benner, R., Kattner, G., Wilhelm, S.W., Kirchman, D.L., Weinbauer, M.G., Luo, T., Chen, F., Azam, F., 2010. Microbial production of recalcitrant dissolved organic matter: longterm carbon storage in the global ocean. Nature Reviews Microbiology 8, 593-599. doi:10.1038/nrmicro2386

Jones, C.G., Gutiérrez, J.L., Byers, J.E., Crooks, J.A., Lambrinos, J.G., Talley, T.S., 2010. A framework for understanding physical ecosystem engineering by organisms. Oikos 119, 1862-1869. doi:10.1111/j.1600-0706.2010.18782.x

Jones, C.G., Lawton, J.H., Shachak, M., 1997. Positive and negative effects of organisms as physical ecosystem engineers. Ecology 78, 1946-1957. doi:10.1890/0012-9658(1997)078[1946:PANEOO]2.0.CO;2

Jones, C.G., Lawton, J.H., Shachak, M., 1994. Organisms as ecosystem engineers. Oikos 69, 373-386. doi: $10.2307 / 3545850$

Kanaya, G., Takagi, S., Kikuchi, E., 2008. Dietary contribution of the microphytobenthos to infaunal deposit feeders in an estuarine mudflat in Japan. Marine Biology 155, 543-553. doi:10.1007/s00227-008-10535

Kingsford, M.J., Leis, J.M., Shanks, A., Lindeman, K.C., Morgan, S.G., Pineda, J., 2002. Sensory environments, larval abilities and local self-recruitment. Bulletin of Marine Science 70, 309-340.

Kirtley, D.W., Tanner, W.F., 1968. Sabellariid worms; builders of a major reef type. Journal of Sedimentary Research 38, 73-78. doi:10.1306/74D718D9-2B21-11D7-8648000102C1865D

Koleff, P., Gaston, K.J., Lennon, J.J., 2003. Measuring beta diversity for presence-absence data. Journal of Animal Ecology 72, 367-382. doi:10.1046/j.1365-2656.2003.00710.x 
Le Cam, J.-B., Fournier, J., Etienne, S., Couden, J., 2011. The strength of biogenic sand reefs: Visco-elastic behaviour of cement secreted by the tube building polychaete Sabellaria alveolata, Linnaeus, 1767. Estuarine, Coastal and Shelf Science 91, 333-339. doi:10.1016/j.ecss.2010.10.036

Lefebvre, S., Marín Leal, J.C., Dubois, S., Orvain, F., Blin, J.-L., Bataillé, M.-P., Ourry, A., Galois, R., 2009. Seasonal dynamics of trophic relationships among co-occurring suspension-feeders in two shellfish culture dominated ecosystems. Estuarine, Coastal and Shelf Science 82, 415-425. doi:10.1016/j.ecss.2009.02.002

Legendre, L., Rassoulzadegan, F., 1996. Food-web mediated export of biogenic carbon in oceans: hydrodynamic control. Marine Ecology Progress Series 145, 179-193. doi:10.3354/meps 145179

Legendre, P., Anderson, M.J., 1999. Distance-based redundancy analysis: testing multispecies responses in multifactorial ecological experiments. Ecological Monographs 69, 1-24. doi:10.1890/00129615(1999)069[0001:DBRATM]2.0.CO;2

Lejart, M., Hily, C., 2011. Differential response of benthic macrofauna to the formation of novel oyster reefs (Crassostrea gigas, Thunberg) on soft and rocky substrate in the intertidal of the Bay of Brest, France. Journal of Sea Research 65, 84-93. doi:10.1016/j.seares.2010.07.004

Lepori, F., Hjerdt, N., 2006. Disturbance and aquatic biodiversity: reconciling contrasting views. BioScience 56, 809-818. doi:10.1641/0006-3568(2006)56[809:DAABRC]2.0.CO;2

Lorenzen, C.J., 1967. Determination of Chlorophyll and Pheo-Pigments: Spectrophotometric Equations. Limnology and Oceanography 12, 343-346. doi:10.4319/lo.1967.12.2.0343

Main, M.B., Nelson, W.G., 1988. Sedimentary characteristics of sabellariid worm reefs (Phragmatopoma lapidosa Kinberg). Estuarine, Coastal and Shelf Science 26, 105-109. doi:10.1016/02727714(88)90015-7

Margiotta, A.M., Shervette, V.R., Hadley, N.H., Plante, C.J., Wilber, D.H., 2016. Species-specific responses of resident crabs to vertical habitat complexity on intertidal oyster reefs. Journal of Experimental Marine Biology and Ecology 477, 7-13. doi:10.1016/j.jembe.2016.01.007

Mateos-Molina, D., Palma, M., Ruiz-Valentín, I., Panagos, P., García-Charton, J.A., Ponti, M., 2015. Assessing consequences of land cover changes on sediment deliveries to coastal waters at regional level over the last two decades in the northwestern Mediterranean Sea. Ocean \& Coastal Management 116, 435-442. doi:10.1016/j.ocecoaman.2015.09.003

Mathers, K.L., Rice, S.P., Wood, P.J., 2017. Temporal effects of enhanced fine sediment loading on macroinvertebrate community structure and functional traits. Science of The Total Environment 599600, 513-522. doi:10.1016/j.scitotenv.2017.04.096

McArdle, B.H., Anderson, M.J., 2001. Fitting multivariate models to community data: a comment on distancebased redundancy analysis. Ecology 82, 290-297. doi:10.1890/00129658(2001)082[0290:FMMTCD]2.0.CO;2

McKindsey, C.W., Archambault, P., Callier, M.D., Olivier, F., 2011. Influence of suspended and off-bottom mussel culture on the sea bottom and benthic habitats: a review. Canadian Journal of Zoology 89, 622646. doi:10.1139/z11-037

McQuaid, K.A., Griffiths, C.L., 2014. Alien reef-building polychaete drives long-term changes in invertebrate biomass and diversity in a small, urban estuary. Estuarine, Coastal and Shelf Science 138, 101-106. doi:10.1016/j.ecss.2013.12.016

Migné, A., Spilmont, N., Boucher, G., Denis, L., Hubas, C., Janquin, M.-A., Rauch, M., Davoult, D., 2009. Annual budget of benthic production in Mont Saint-Michel Bay considering cloudiness, microphytobenthos migration, and variability of respiration rates with tidal conditions. Continental Shelf Research 29, 2280-2285. doi:10.1016/j.csr.2009.09.004

Miller, D.C., Muir, C.L., Hauser, O.A., 2002. Detrimental effects of sedimentation on marine benthos: what can be learned from natural processes and rates? Ecological Engineering 19, 211-232. doi:10.1016/S09258574(02)00081-2

Muir, A.P., Nunes, F.L.D., Dubois, S.F., Pernet, F., 2016. Lipid remodelling in the reef-building honeycomb worm, Sabellaria alveolata, reflects acclimation and local adaptation to temperature. Scientific Reports 6. doi:10.1038/srep35669

Newell, R.I.E., Cornwell, J.C., Owens, M.S., 2002. Influence of simulated bivalve biodeposition and microphytobenthos on sediment nitrogen dynamics: A laboratory study. Limnol. Oceanogr. 47, 13671379. doi:10.4319/lo.2002.47.5.1367

Noernberg, M.A., Fournier, J., Dubois, S., Populus, J., 2010. Using airborne laser altimetry to estimate Sabellaria alveolata (Polychaeta: Sabellariidae) reefs volume in tidal flat environments. Estuarine, Coastal and Shelf Science 90, 93-102. doi:10.1016/j.ecss.2010.07.014

Norling, P., Kautsky, N., 2007. Structural and functional effects of Mytilus edulis on diversity of associated species and ecosystem functioning. Marine Ecology Progress Series 351, 163-175. doi:10.3354/meps07033 
Oksanen, J., Blanchet, G.F., Friendly, M., Kindt, R., Legendre, P., McGlinn, D., Minchin, P.R., O’Hara, R.B., Simpson, G.L., Solymos, P., Stevens, M.H.H., Szoecs, E., Wagner, H., 2016. Vegan: community ecology package.

Pascal, P.-Y., Dupuy, C., Richard, P., Mallet, C., Telet, E.A. du C., Niquilb, N., 2009. Seasonal variation in consumption of benthic bacteria by meio- and macrofauna in an intertidal mudflat. Limnology and Oceanography 54, 1048-1059. doi:10.4319/lo.2009.54.4.1048

Pascal, P.-Y., Dupuy, C., Richard, P., Rzeznik-Orignac, J., Niquil, N., 2008. Bacterivory of a mudflat nematode community under different environmental conditions. Marine Biology 154, 671-682. doi:10.1007/s00227-008-0960-9

Passarelli, C., Olivier, F., Paterson, D.M., Meziane, T., Hubas, C., 2014. Organisms as cooperative ecosystem engineers in intertidal flats. Journal of Sea Research 92, 92-101. doi:10.1016/j.seares.2013.07.010

Pawlik, J.R., 1988. Larval settlement and metamorphosis of two gregarious sabellariid polychaetes: Sabellaria alveolata compared with Phragmatopoma californica. Journal of the Marine Biological Association of the United Kingdom 68, 101-124. doi:10.1017/S002531540005013X

Plicanti, A., Domínguez, R., Dubois, S.F., Bertocci, I., 2016. Human impacts on biogenic habitats: Effects of experimental trampling on Sabellaria alveolata (Linnaeus, 1767) reefs. Journal of Experimental Marine Biology and Ecology 478, 34-44. doi:10.1016/j.jembe.2016.02.001

Porta, B.L., Nicoletti, L., 2009. Sabellaria alveolata (Linnaeus) reefs in the central Tyrrhenian Sea (Italy) and associated polychaete fauna. Zoosymposia 2, 527-536. doi:10.11646/zoosymposia.2.1.36

R Core Team, 2016. R: A Language and Environment for Statistical Computing. R Foundation for Statistical Computing, Vienna, Austria.

Rigolet, C., Dubois, S.F., Thiébaut, E., 2014. Benthic control freaks: Effects of the tubiculous amphipod Haploops nirae on the specific diversity and functional structure of benthic communities. Journal of Sea Research 85, 413-427. doi:10.1016/j.seares.2013.07.013

Schlund, E., Basuyaux, O., Lecornu, B., Pezy, J.-P., Baffreau, A., Dauvin, J.-C., 2016. Macrofauna associated with temporary Sabellaria alveolata reefs on the west coast of Cotentin (France). SpringerPlus 5, 1260. doi:10.1186/s40064-016-2885-y

Skalski, J.R., Ryding, K.E., Millspaugh, J.J., 2005. Analysis of population indices, in: Wildlife Demography: Analysis of Sex, Age, and Count Data. Academic Press, pp. 359-434.

Snelgrove, P.V.R., Butman, C.A., 1994. Animal-sediment relationships revisited: cause versus effect. Oceanography and Marine Biology: An Annual Review.

Snelgrove, P.V.R., Butman, C.A., Grassle, J.P., 1993. Hydrodynamic enhancement of larval settlement in the bivalve Mulinia lateralis (Say) and the polychaete Capitella sp. I in microdepositional environments. Journal of Experimental Marine Biology and Ecology 168, 71-109. doi:10.1016/0022-0981(93)90117-7

Stachowicz, J.J., 2001. Mutualism, facilitation, and the structure of ecological communities positive interactions play a critical, but underappreciated, role in ecological communities by reducing physical or biotic stresses in existing habitats and by creating new habitats on which many species depend. BioScience 51, 235-246. doi:10.1641/0006-3568(2001)051[0235:MFATSO]2.0.CO;2

Thorin, S., Radureau, A., Feunteun, E., Lefeuvre, J.-C., 2001. Preliminary results on a high east-west gradient in the macrozoobenthic community structure of the macrotidal Mont Saint-Michel bay. Continental Shelf Research 21, 2167-2183. doi:10.1016/S0278-4343(01)00050-4

Ubertini, M., Lefebvre, S., Rakotomalala, C., Orvain, F., 2015. Impact of sediment grain-size and biofilm age on epipelic microphytobenthos resuspension. Journal of Experimental Marine Biology and Ecology 467, 52-64. doi:10.1016/j.jembe.2015.02.007

Underwood, A.J., 1997. Experiments in ecology: their logical design and interpretation using analysis of variance. Cambridge University Press.

van Broekhoven, W., Jansen, H., Verdegem, M., Struyf, E., Troost, K., Lindeboom, H., Smaal, A., 2015. Nutrient regeneration from feces and pseudofeces of mussel Mytilus edulis spat. Marine Ecology Progress Series 534, 107-120. doi:10.3354/meps11402

van Broekhoven, W., Troost, K., Jansen, H., Smaal, A., 2014. Nutrient regeneration by mussel Mytilus edulis spat assemblages in a macrotidal system. Journal of Sea Research 88, 36-46. doi:10.1016/j.seares.2013.12.007

Veiga, P., Torres, A.C., Aneiros, F., Sousa-Pinto, I., Troncoso, J.S., Rubal, M., 2016. Consistent patterns of variation in macrobenthic assemblages and environmental variables over multiple spatial scales using taxonomic and functional approaches. Marine Environmental Research 120, 191-201. doi:10.1016/j.marenvres.2016.08.011

Venables, W.N., Ripley, B.D., 2002. Modern Applied Statistics with S, Fourth. ed. Springer, New York.

Watson, G.J., Murray, J.M., Schaefer, M., Bonner, A., Gillingham, M., 2017. Assessing the impacts of bait collection on inter-tidal sediment and the associated macrofaunal and bird communities: The 


\section{Figure captions}

Fig. 1. Schematic overview presenting the habitat modifications caused by (1) the establishment of an ecosystem engineer and (2) disturbances of the engineered sediment. Recruitment of S. alveolata leads to the formation of a biologically modified sediment (engineered sediment) and to a soft sediment under the influence of the

Fig. 2. PCO analysis of macrobenthos associated with the three sediment types in late winter. The analysis is based on Bray-Curtis similarities of log transformed density data. The black diamonds, the grey squares and the light grey circles represent the engineered, the associated and the control sediment samples respectively. Vectors represent species correlating more than $60 \%$ with one of the first two PCO axes. The correlations are based on Spearman coefficients. ASIM: Achelia simplex, CEDU: Cerastoderma edule, CFOR: Crepidula fornicata, umbilicalis, GVUL: Golfingia vulgaris, LBAL: Limecola balthica, LLEV: Lekanesphaera levii, LRUG: Lekanesphaera rugicauda, McfGAL: Mytilus cf. galloprovincialis, MFRA: Mediomastus fragilis, MGIG: 

cultrifera, PPLA: Porcellana platycheles.

Fig. 3. PCO analysis of macrobenthos associated with the three sediment types in late summer. The analysis is based on Bray-Curtis similarities of log transformed density data. The black diamonds, the grey squares and the light grey circles represent the engineered, the associated and the control sediment samples respectively. Vectors represent species correlating more than $60 \%$ with one of the first two PCO axes. The correlations are based on Spearman coefficients. AECH: Achelia echinata, ALAE: Achelia laevis, ASIM: Achelia simplex, CEDU: Cerastoderma edule, CMAE: Carcinus maenas, CVOL: Corophium volutator, EORN: Eulalia ornata, GBOB: Goniadella bobrezkii, GMAX: Gnathia maxillaris, GUMB: Gibbula umbilicalis, GVUL: Golfingia vulgaris,

LBAL: Limecola balthica, LCON: Lanice conchilega, LLEV: Lekanesphaera levii, LRUG: Lekanesphaera rugicauda, MARE: Malmgrenia arenicolae, McfGAL: Mytilus cf. galloprovincialis, MFRA: Mediomastus fragilis, MGIG: Magallana gigas, MPAL: Melita palmata, NCIR: Nephtys cirrosa, NEMA: Nematoda spp., NEME: Nemerte sp., NHOM: Nephtys hombergii, NLAP: Nucella lapillus, NMIN: Nephasoma minutum, OCTE: Odontosyllis ctenostoma, PCUL: Perinereis cultrifera, PPLA: Porcellana platycheles.

Fig. 4. dbRDA plots based on a) the late winter data set and b) the late summer data set and representing the three sediment type macrofauna composition as explained by the set of environmental parameters composing the most parsimonious explanatory model. Vectors represent the environmental parameters selected by the DistLM routine. The black diamonds, the grey squares and the light grey circles represent the engineered, the associated

Fig. 5. Late winter nMDS ordination plots of the benthic macrofauna assemblages based on a) the Sørensen total beta diversity, b) the nestedness component of the total beta diversity, c) the Bray-Curtis index of dissimilarity and d) the abundance gradient component of the Bray-Curtis dissimilarity. The stress value of the nMDS is indicated on each plot. The lines indicate the different fitted mud contents obtained using the 'ordisurf' function.

Fig. 6. Late summer nMDS ordination plots of the macrofauna benthic assemblages based on a) the Sørensen total beta diversity, b) the turnover component of the total beta diversity, c) the nestedness component of the total beta diversity, d) the Bray-Curtis index of dissimilarity, e) the abundance gradient component of the Bray- 


\section{ACCEPTED MANUSCRIPT}

1116 Curtis dissimilarity and f) the balanced variation in abundances component of the Bray-Curtis dissimilarity. The

1117

1118

1119

1120

1121

1122

1123

1124

1125

1126

1127

1128

1129

1130 stress value of the nMDS is indicated on each plot. The lines indicate the different fitted mud contents obtained using the 'ordisurf' function. 


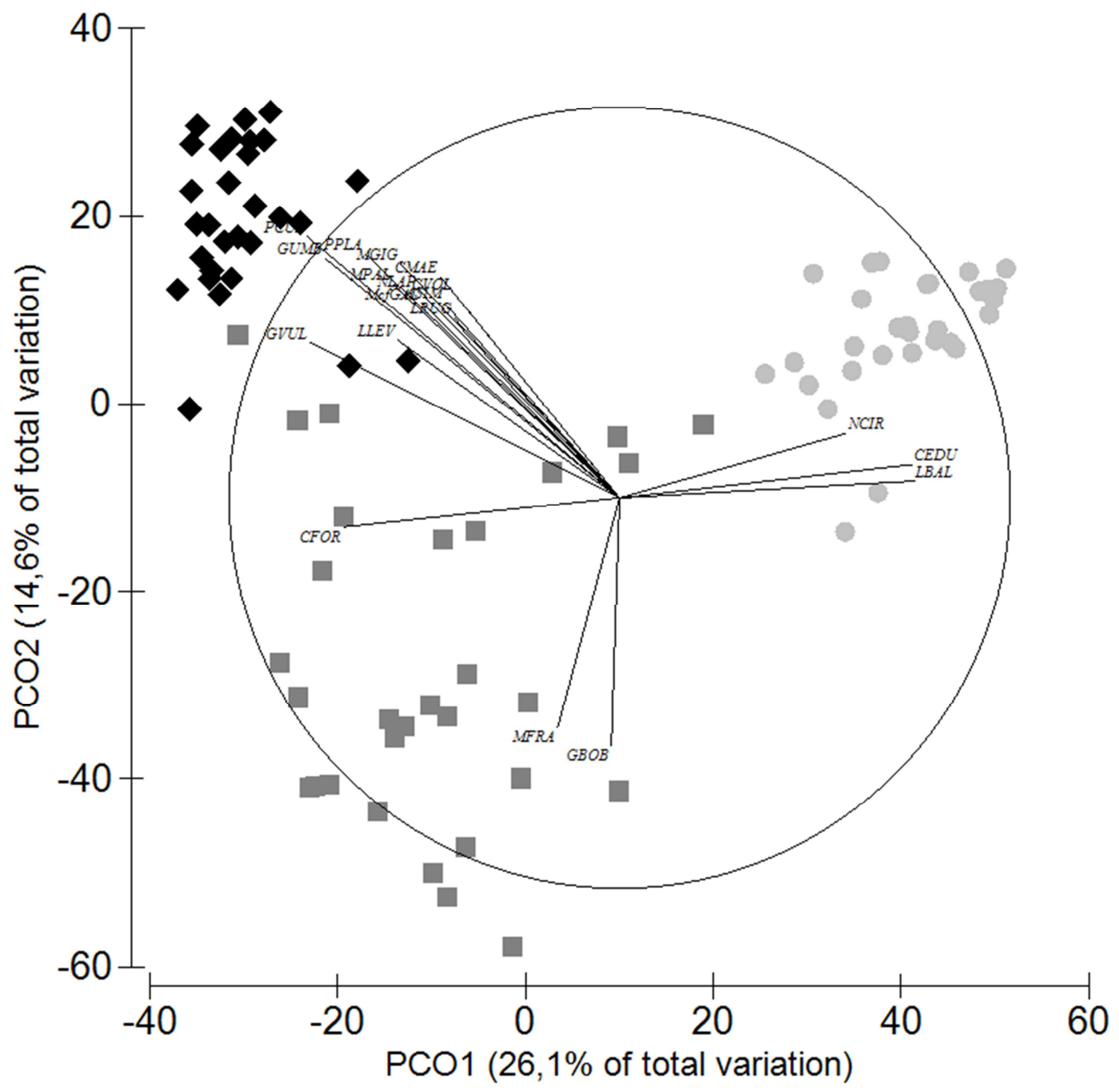

1134

1135 Fig. 2.

1136 


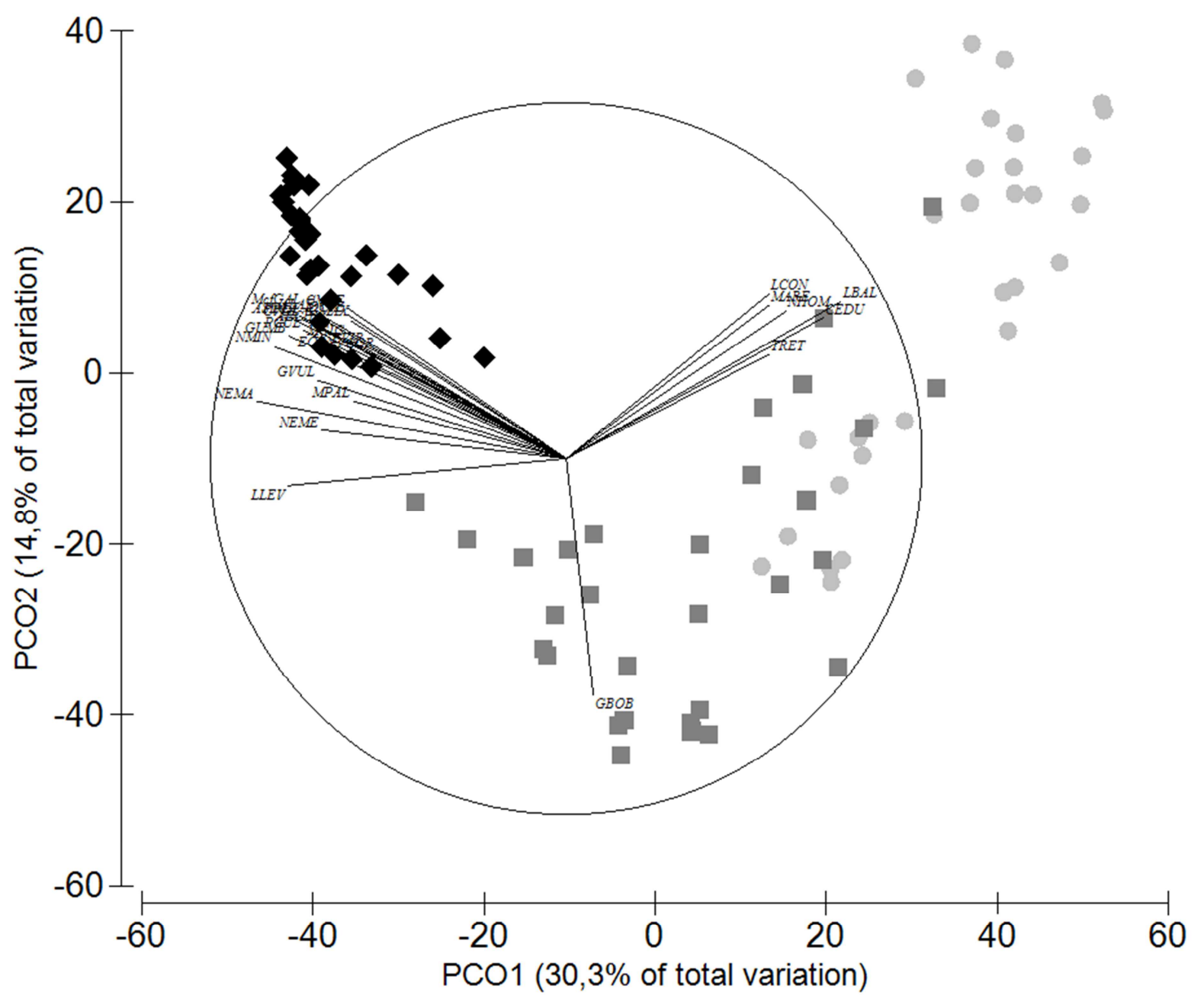

1137

Fig. 3.

1139

1140 


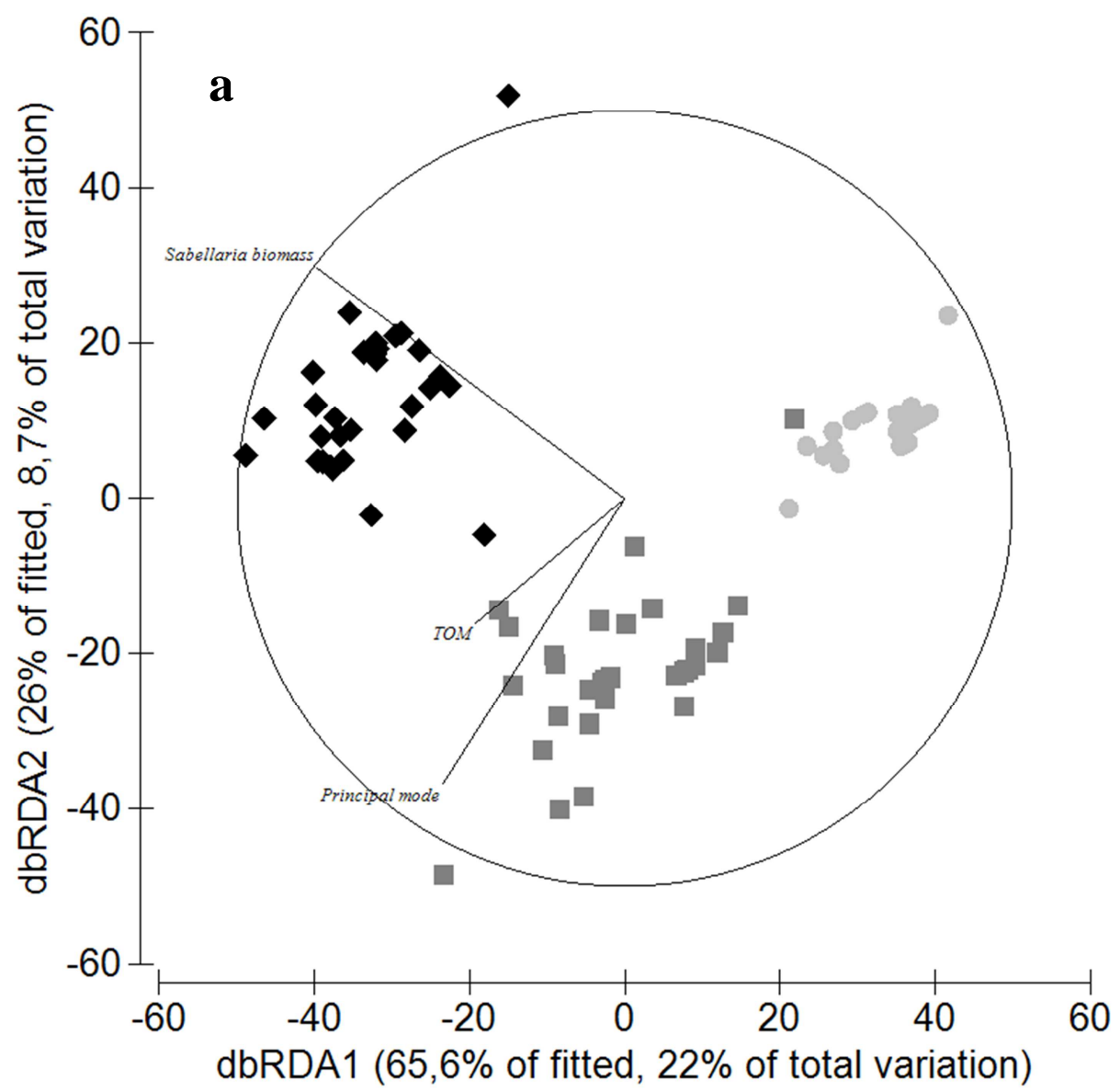

1141

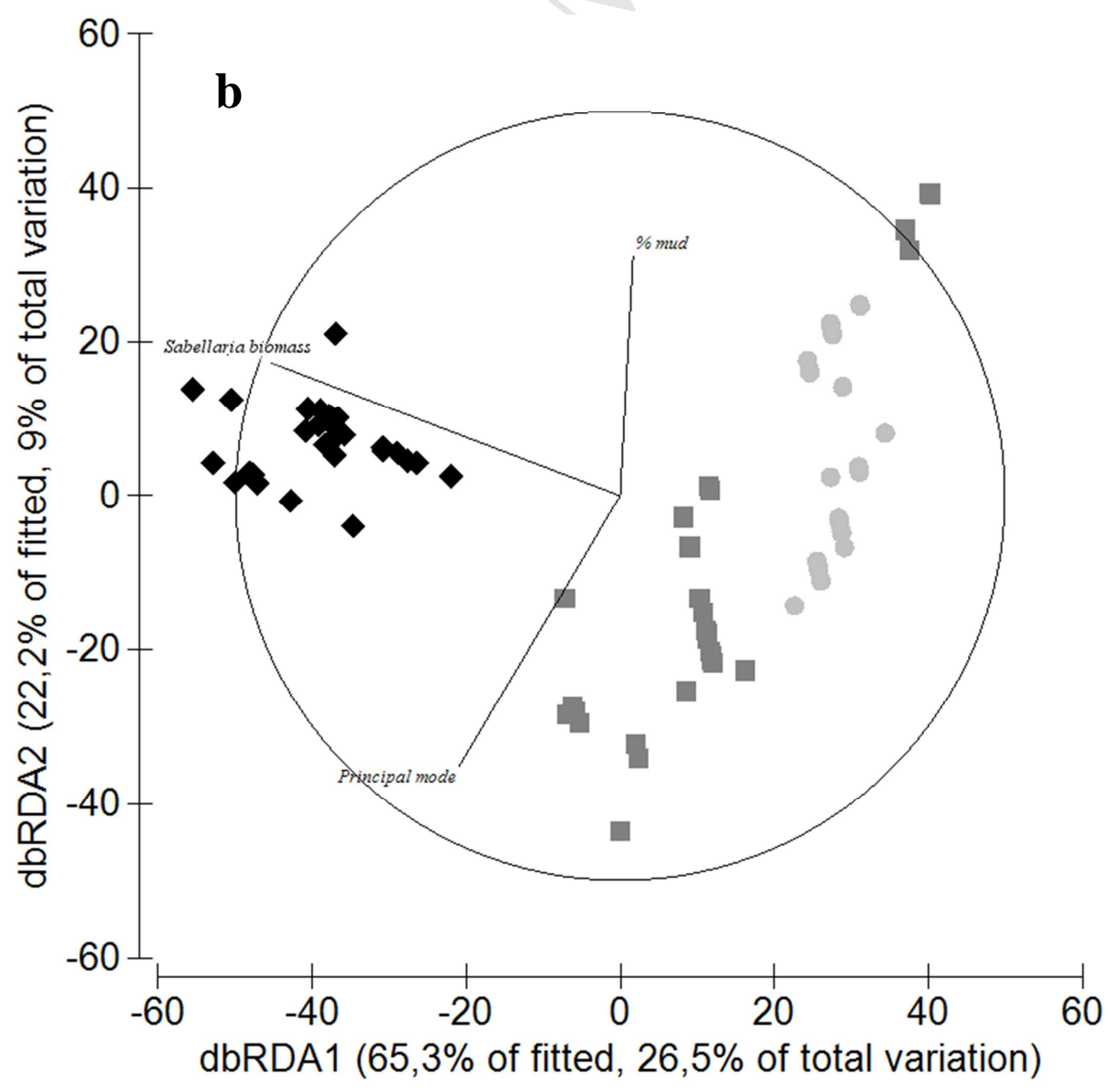


Fig. $4 a$ and $b$.
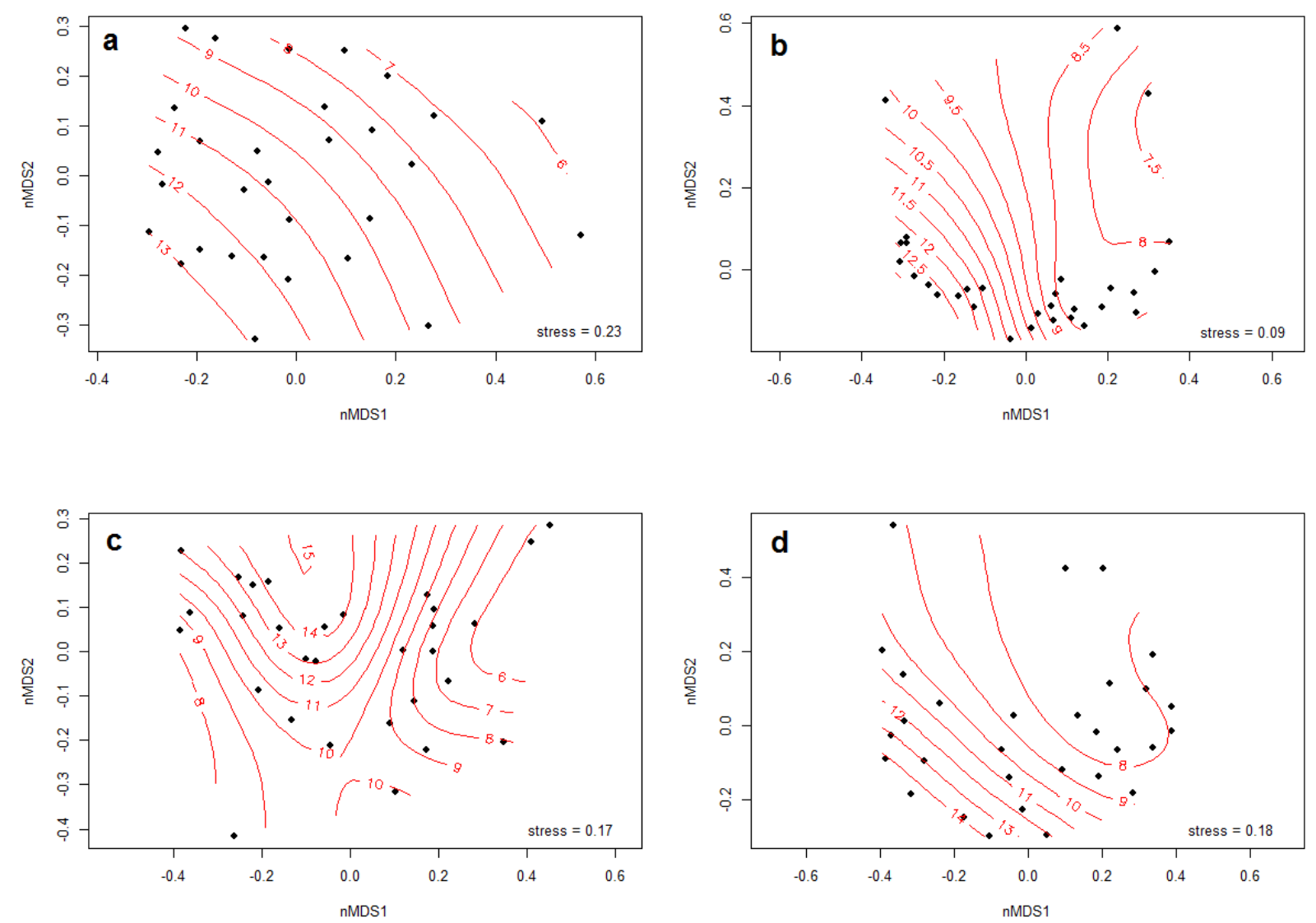

1144

Fig. 5. 

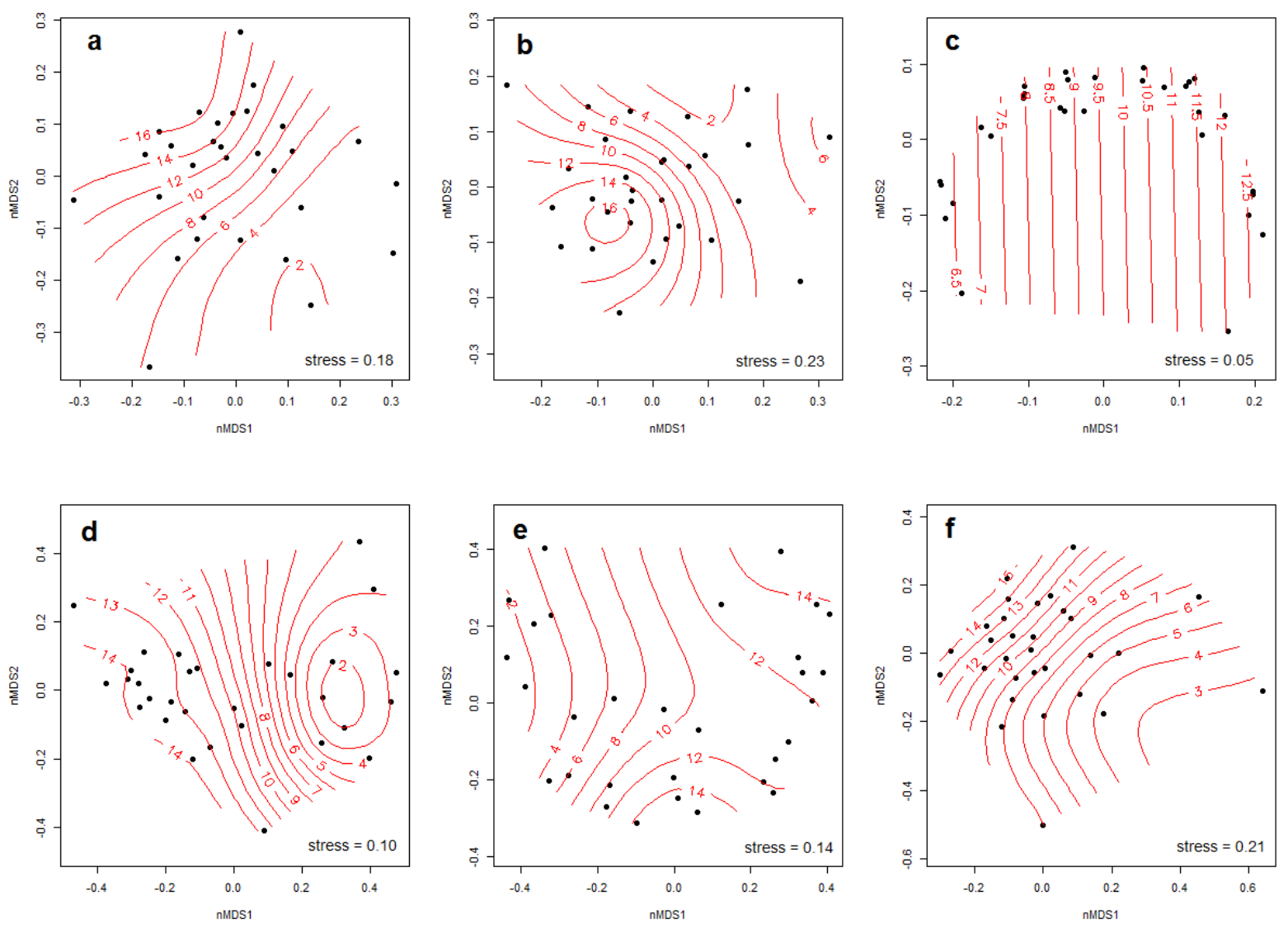

1146

1147

Fig. 6.

1148

1149

1150

1151

1152

1153

1154

1155

1156

1157

1158

1159

1160 
1161 Tables 1, 2 and 3

1162 Table 1 Mean values ( \pm standard errors) for (a) the grain-size parameters of the three sediment types

1163 (engineered, associated and control) and (b) the environmental parameters for the associated and the control

1164 sediments. Significant differences $(\mathrm{p}<0.05)$ of the one-way ANOVAs are in bold and for (a), post-hoc results

1165 are designated by superscript letters indicating homogenous groups of samples. TOM: total organic matter

1166 content, Chl $a$ : chlorophyll $a$ concentration, Pheo: pheopigments concentration, Sol: soluble carbohydrates

1167 concentration, Ins/Sol: ratio of the concentration of insoluble carbohydrates on soluble carbohydrates.

\begin{tabular}{|c|c|c|c|c|c|c|c|c|}
\hline \multirow[t]{2}{*}{ (a) } & \multicolumn{4}{|c|}{ Late winter } & \multicolumn{4}{|c|}{ Late summer } \\
\hline & Engineered & Associated & Control & $p$-value & Engineered & Associated & Control & $p$-value \\
\hline $\begin{array}{l}\text { Principal } \\
\text { mode }(\mu \mathrm{m})\end{array}$ & $688 \pm 35^{\mathrm{a}}$ & $1010 \pm 118^{\mathrm{a}}$ & $186 \pm 8^{b}$ & $<0.001$ & $618 \pm 8^{\mathrm{a}}$ & $692 \pm 74^{\mathrm{a}}$ & $201 \pm 9^{b}$ & $<0.001$ \\
\hline $\begin{array}{l}\text { Sorting index } \\
\left(\mathbf{S}_{\mathbf{0}}\right)\end{array}$ & $1.71 \pm 0.05^{\mathrm{a}}$ & $1.72 \pm 0.05^{\mathrm{a}}$ & $2.97 \pm 0.34^{\mathrm{b}}$ & $<0.001$ & $1.69 \pm 0.05^{\mathrm{a}}$ & $2.98 \pm 0.45^{\mathrm{b}}$ & $2.70 \pm 0.37^{\mathrm{b}}$ & 0.018 \\
\hline $\begin{array}{l}\operatorname{Mud}(\%) \\
(<63 \mu \mathrm{m})\end{array}$ & $10.00 \pm 0.83^{\mathrm{a}}$ & $1.84 \pm 0.44^{\mathrm{b}}$ & $27.38 \pm 3.62^{\mathrm{a}}$ & $<0.001$ & $9.59 \pm 1.22^{\mathrm{a}}$ & $20.47 \pm 5.37^{\mathrm{a}}$ & $21.61 \pm 5.23^{\mathrm{a}}$ & 0.106 \\
\hline $\begin{array}{l}\text { Sand }(\%) \\
(63-200 \mu \mathrm{m})\end{array}$ & $87.19 \pm 0.83^{\mathrm{a}}$ & $76.74 \pm 1.40^{\mathrm{b}}$ & $71.69 \pm 3.53^{b}$ & $<0.001$ & $85.77 \pm 1.40^{\mathrm{a}}$ & $65.11 \pm 4.09^{b}$ & $76.79 \pm 5.17^{\mathrm{ab}}$ & 0.001 \\
\hline 1168 & & & & & & & & \\
\hline (b) & & & ate winter & & 20 & Late & e summer & \\
\hline & & ssociated & Control & $p-v a$ & Ass & ciated & Control & $p$-value \\
\hline TOM (\%) & & $96 \pm 0.72$ & $2.70 \pm 0.30$ & $<0.0$ & 4.9 & \pm 0.59 & $2.26 \pm 0.28$ & $<0.001$ \\
\hline Chl $a\left(\mu g . g^{-1}\right.$ se & (ment) & $.21 \pm 2.49$ & $2.83 \pm 0.58$ & 0.00 & 13.3 & \pm 2.24 & $3.92 \pm 0.88$ & 0.002 \\
\hline Pheo $\left(\mu g g^{-1}\right.$ se & ment) & $.54 \pm 0.36$ & $16.18 \pm 0.36$ & 0.00 & 15.5 & \pm 0.53 & $15.41 \pm 0.29$ & 0.826 \\
\hline Sol $\left(\mu g \cdot g^{-1}\right.$ sedi & ent) & $442 \pm 72$ & $113 \pm 25$ & 0.00 & & \pm 78 & $120 \pm 25$ & $<0.001$ \\
\hline Ins/Sol & & $59 \pm 2.29$ & $8.63 \pm 0.37$ & 0.99 & & \pm 0.43 & $6.32 \pm 0.33$ & 0.5175 \\
\hline
\end{tabular}

\section{9}

1170

1171

1172

1173

1174

1175

1176

1177

1178

1179

1180 
1181 Table 2 Mean values ( \pm standard errors) for the total macrofauna density (number of individuals. $\mathrm{m}^{-2}$ ), N0, N1

1182 and N2 with (a) Sabellaria taken into account and (b) Sabellaria excluded, for the three sediment types

1183 (engineered, associated and control) and at both sampling periods (late winter and late summer). N0 represents

1184 the species richness, N1 the exponential of the Shannon-Winner diversity and N2 the inverse of the Simpson

1185 dominance index. Significant differences $(\mathrm{p}<0.05)$ of the one-way ANOVAs are in bold and post-hoc results

1186 are designated by superscript letters indicating homogenous groups of samples.

Late winter

Late summer

(a) Macrofauna (Sabellaria included in the analyses)

\begin{tabular}{|c|c|c|c|c|c|c|c|c|}
\hline & Engineered & Associated & Control & p-value & Engineered & Associated & Control & $p$-value \\
\hline Density & $10067 \pm 841^{\mathrm{a}}$ & $585 \pm 102^{b}$ & $629 \pm 109^{b}$ & $<0.001$ & $23911 \pm 2530^{\mathrm{a}}$ & $1029 \pm 156^{b}$ & $1403 \pm 351^{b}$ & $<0.001$ \\
\hline No & $17 \pm 1^{\mathrm{a}}$ & $7 \pm 1^{\mathrm{b}}$ & $8 \pm 1^{b}$ & $<0.001$ & $26 \pm 1^{\mathrm{a}}$ & $9 \pm 1^{b}$ & $10 \pm 1^{\mathrm{b}}$ & $<0.001$ \\
\hline N1 & $2.92 \pm 0.37^{\mathrm{a}}$ & $4.46 \pm 0.50^{\mathrm{b}}$ & $4.54 \pm 0.37^{b}$ & 0.013 & $6.01 \pm 0.65^{\mathrm{a}}$ & $4.61 \pm 0.38^{\mathrm{a}}$ & $5.22 \pm 0.28^{\mathrm{a}}$ & 0.229 \\
\hline $\mathbf{N} 2$ & $1.87 \pm 0.23^{\mathrm{a}}$ & $3.75 \pm 0.40^{b}$ & $3.60 \pm 0.28^{b}$ & $<0.001$ & $3.93 \pm 0.44^{\mathrm{a}}$ & $3.44 \pm 0.30^{\mathrm{a}}$ & $4.04 \pm 0.25^{\mathrm{a}}$ & 0.315 \\
\hline \multicolumn{9}{|c|}{ (b) Macrofauna (Sabellaria excluded from the analyses) } \\
\hline & Engineered & Associated & Control & p-value & Engineered & Associated & Control & $p$-value \\
\hline Density & $2385 \pm 518^{a}$ & $538 \pm 91^{b}$ & $629 \pm 109^{b}$ & $<0.001$ & $11066 \pm 1814^{\mathrm{a}}$ & $981 \pm 137^{b}$ & $1403 \pm 351^{\mathrm{b}}$ & $<0.001$ \\
\hline No & $16 \pm 1^{\mathrm{a}}$ & $7 \pm 1^{b}$ & $8 \pm 1^{b}$ & $<0.001$ & $25 \pm 1^{\mathrm{a}}$ & $9 \pm 1^{b}$ & $10 \pm 1^{\mathrm{b}}$ & $<0.001$ \\
\hline N1 & $7.73 \pm 0.51^{\mathrm{a}}$ & $4.30 \pm 0.49^{b}$ & $4.54 \pm 0.37^{\mathrm{b}}$ & $<0.001$ & $9.00 \pm 0.52^{\mathrm{a}}$ & $4.51 \pm 0.37^{\mathrm{b}}$ & $5.22 \pm 0.28^{b}$ & $<0.001$ \\
\hline $\mathbf{N} 2$ & $5.63 \pm 0.42^{\mathrm{a}}$ & $3.64 \pm 0.39^{b}$ & $3.60 \pm 0.28^{b}$ & $<0.001$ & $5.82 \pm 0.38^{\mathrm{a}}$ & $3.36 \pm 0.30^{\mathrm{b}}$ & $4.04 \pm 0.25^{\mathrm{b}}$ & $<0.001$ \\
\hline
\end{tabular}


Table 3 Results of the Mantel tests between (a) the different beta diversity matrices and the mud content distance matrix and (b) the different abundance-based dissimilarity matrices and the mud content distance matrix at both sampling periods (late winter and late summer). $\beta_{\text {sor }}$ is the Sørensen pairwise dissimilarity and accounts for the total beta diversity, $\beta_{\text {sim }}$ is the Simpson pairwise dissimilarity and accounts for the turnover component of the total beta diversity, $\beta_{\text {nes }}$ is the nestedness-resultant dissimilarity and accounts for the nestedness component of the total beta diversity; $\beta_{\text {sor }}=\beta_{\text {sim }}+\beta_{\text {nes. }}$. $d_{B C}$ is the Bray-Curtis index of dissimilarity and accounts for the total abundance-based dissimilarity, $\mathrm{d}_{\mathrm{BC}-\text { bal }}$ is the balanced variation in abundances component of the Bray-Curtis dissimilarity and is equivalent to an abundance-based turnover, $\mathrm{d}_{\mathrm{BC} \text {-gra }}$ is the abundance gradient component of Bray-Curtis dissimilarity and is equivalent to an abundance-based nestedness; $\mathrm{d}_{\mathrm{BC}}=\mathrm{d}_{\mathrm{BC} \text {-bal }}+\mathrm{d}_{\mathrm{BC}-\text {-gra }}$. Significant simulated $\mathrm{p}$-values $(\mathrm{p}<0.05)$ and associated observed correlation are in bold.

\begin{tabular}{ccc}
\hline \multicolumn{2}{c}{ Late winter } & \multicolumn{2}{c}{ Late summer } \\
\hline Observed correlation $r \quad$ Simulated $p$-value & Observed correlation $r$ & Simulated $p$-value
\end{tabular}

(a) Beta diversity indices

\begin{tabular}{lcccc}
\hline $\boldsymbol{\beta}_{\text {sor }}$ & 0.13 & 0.070 & $\mathbf{0 . 2 4}$ & $<\mathbf{0 . 0 0 1}$ \\
\hline $\boldsymbol{\beta}_{\text {sim }}$ & 0.066 & 0.23 & $\mathbf{0 . 1 5}$ & $\mathbf{0 . 0 0 6 6}$ \\
\hline $\boldsymbol{\beta}_{\text {nes }}$ & 0.032 & 0.33 & 0.077 & 0.094
\end{tabular}

(b) Abundance based dissimilarity indices

\begin{tabular}{lcccc}
\hline $\mathbf{d}_{\text {BC }}$ & 0.14 & 0.052 & $\mathbf{0 . 3 8}$ & $<\mathbf{0 . 0 0 1}$ \\
\hline $\mathbf{d}_{\text {BC-bal }}$ & 0.050 & 0.28 & 0.058 & 0.18 \\
\hline $\mathbf{d}_{\text {BC-gra }}$ & 0.046 & 0.28 & $\mathbf{0 . 2 9}$ & $<\mathbf{0 . 0 0 1}$
\end{tabular}




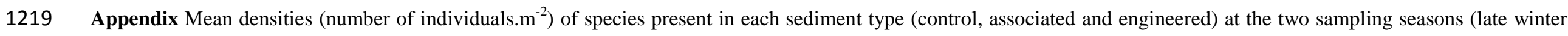
1220 and late summer). The mean densities were calculated using the ten stations sampled in each sediment type and at each season.

\begin{tabular}{|c|c|c|c|c|c|c|c|}
\hline & \multirow[t]{2}{*}{ Species } & \multicolumn{3}{|c|}{ Late winter } & \multicolumn{3}{|c|}{ Late summer } \\
\hline & & Control & Associated & Engineered & Control & Associated & Engineered \\
\hline \multirow[t]{26}{*}{ Polychaete } & Acromegalomma vesiculosum & 0.00 & 0.00 & 0.00 & 0.00 & 0.00 & 2.48 \\
\hline & Ampharete baltica & 0.00 & 0.00 & 0.00 & 0.00 & 1.24 & 0.00 \\
\hline & Aonides oxycephala & 0.00 & 1.24 & 0.00 & 0.00 & 0.00 & 0.00 \\
\hline & Aonides paucibranchiata & 0.00 & 0.00 & 0.00 & 0.00 & 6.20 & 0.00 \\
\hline & Armandia polyophthalma & 1.24 & 0.00 & 0.00 & 0.00 & 0.00 & 0.00 \\
\hline & Capitella capitata & 6.20 & 0.00 & 0.00 & 1.24 & 0.00 & 1.24 \\
\hline & Caulleriella alata & 0.00 & 0.00 & 0.00 & 1.24 & 0.00 & 0.00 \\
\hline & Cirriformia tentaculata & 0.00 & 35.96 & 0.00 & 0.00 & 42.16 & 4.96 \\
\hline & Dipolydora flava & 0.00 & 0.00 & 0.00 & 0.00 & 0.00 & 4.96 \\
\hline & Eteone flava & 0.00 & 0.00 & 0.00 & 1.24 & 0.00 & 0.00 \\
\hline & Eteone longa & 0.00 & 0.00 & 0.00 & 3.72 & 3.72 & 0.00 \\
\hline & Eulalia aurea & 0.00 & 0.00 & 3.72 & 0.00 & 0.00 & 0.00 \\
\hline & Eulalia clavigera & 0.00 & 0.00 & 9.92 & 0.00 & 0.00 & 1.24 \\
\hline & Eulalia ornata & 0.00 & 0.00 & 1.24 & 0.00 & 0.00 & 93.01 \\
\hline & Eulalia viridis & 0.00 & 0.00 & 22.32 & 0.00 & 0.00 & 27.28 \\
\hline & Eumida arctica & 0.00 & 0.00 & 0.00 & 0.00 & 0.00 & 1.24 \\
\hline & Eumida sanguinea & 12.40 & 1.24 & 16.12 & 14.88 & 0.00 & 47.12 \\
\hline & Eunereis longissima & 0.00 & 0.00 & 0.00 & 3.72 & 0.00 & 0.00 \\
\hline & Glycera alba & 3.72 & 4.96 & 2.48 & 13.64 & 13.64 & 1.24 \\
\hline & Glycera tridactyla & 0.00 & 1.24 & 0.00 & 0.00 & 1.24 & 0.00 \\
\hline & Goniadella bobrezkii & 1.24 & 228.17 & 0.00 & 14.88 & 189.73 & 11.16 \\
\hline & Lanice conchilega & 62.00 & 0.00 & 0.00 & 602.67 & 8.68 & 0.00 \\
\hline & Lepidonotus squamatus & 0.00 & 0.00 & 2.48 & 0.00 & 0.00 & 0.00 \\
\hline & Magelona johnstoni & 1.24 & 0.00 & 0.00 & 1.24 & 0.00 & 0.00 \\
\hline & Malacoceros fuliginosus & 1.24 & 0.00 & 0.00 & 3.72 & 0.00 & 0.00 \\
\hline & Malmgrenia arenicolae & 6.20 & 3.72 & 0.00 & 142.61 & 2.48 & 0.00 \\
\hline
\end{tabular}


Mediomastus fragilis

Myrianida sp.

Mysta picta

Nephtys cirrosa

Nephtys hombergii

Nephtys sp.

Notomastus latericeus

Odontosyllis ctenostoma

Odontosyllis gibba

Parathelepus collaris

Perinereis cultrifera

Pholoe inornata

Phyllodoce laminosa

Phyllodoce mucosa

Polycirrus aurantiacus

Polycirrus sp.

Protodorvillea kefersteini

Pseudopolydora pulchra

Pseudopotamilla reniformis

Pygospio elegans

Sabellaria alveolata

Saccocirrus papillocercus

Scalibregma celticum

Scolelepis (Parascolelepis) tridentata

Scolelepis (Scolelepis) cantabra

Scoloplos (Scoloplos) armiger

Sphaerosyllis bulbosa

Sphaerosyllis sp.

Spio martinensis

Spio symphyta

Spirobranchus lamarcki

$\begin{array}{rrrrrr}6.20 & 65.72 & 6.20 & 13.64 & 280.26 & 44.64 \\ 0.00 & 2.48 & 0.00 & 0.00 & 0.00 & 0.00 \\ 1.24 & 0.00 & 0.00 & 0.00 & 0.00 & 0.00 \\ 59.52 & 0.00 & 0.00 & 54.56 & 8.68 & 0.00 \\ 17.36 & 0.00 & 0.00 & 55.80 & 38.44 & 0.00 \\ 1.24 & 0.00 & 0.00 & 0.00 & 0.00 & 0.00 \\ 16.12 & 2.48 & 1.24 & 48.36 & 2.48 & 48.36 \\ 0.00 & 1.24 & 12.40 & 0.00 & 0.00 & 271.57 \\ 0.00 & 1.24 & 29.76 & 0.00 & 0.00 & 0.00 \\ 0.00 & 0.00 & 0.00 & 0.00 & 1.24 & 49.60 \\ 0.00 & 7.44 & 164.93 & 0.00 & 1.24 & 146.33 \\ 0.00 & 0.00 & 1.24 & 1.24 & 0.00 & 7.44 \\ 0.00 & 0.00 & 2.48 & 0.00 & 0.00 & 11.16 \\ 0.00 & 0.00 & 0.00 & 11.16 & 0.00 & 0.00 \\ 0.00 & 3.72 & 0.00 & 0.00 & 0.00 & 0.00 \\ 0.00 & 0.00 & 7.44 & 0.00 & 0.00 & 0.00 \\ 0.00 & 1.24 & 0.00 & 0.00 & 6.20 & 0.00 \\ 0.00 & 1.24 & 0.00 & 0.00 & 0.00 & 0.00 \\ 0.00 & 0.00 & 0.00 & 0.00 & 0.00 & 3.72 \\ 4.96 & 0.00 & 0.00 & 0.00 & 0.00 & 6.20 \\ 0.00 & 47.12 & 7682.22 & 0.00 & 48.36 & 12844.62 \\ 0.00 & 1.24 & 0.00 & 0.00 & 13.64 & 0.00 \\ 0.00 & 1.24 & 0.00 & 0.00 & 0.00 & 0.00 \\ 1.24 & 0.00 & 0.00 & 0.00 & 0.00 & 0.00 \\ 0.00 & 0.00 & 0.00 & 0.00 & 2.48 & 0.00 \\ 14.88 & 0.00 & 0.00 & 4.96 & 0.00 & 0.00 \\ 0.00 & 0.00 & 0.00 & 0.00 & 14.88 & 7.44 \\ 0.00 & 1.24 & 0.00 & 0.00 & 0.00 & 0.00 \\ 6.20 & 0.00 & 0.00 & 0.00 & 0.00 & 0.00 \\ 0.00 & 0.00 & 0.00 & 2.48 & 0.00 & 0.00 \\ 0.00 & 22.32 & 24.80 & 0.00 & 14.88 & 68.20\end{array}$




\begin{tabular}{|c|c|c|c|c|c|c|c|}
\hline & Spirobranchus triqueter & 0.00 & 0.00 & 1.24 & 0.00 & 0.00 & 0.00 \\
\hline & Sthenelais boa & 0.00 & 0.00 & 1.24 & 0.00 & 0.00 & 0.00 \\
\hline & Syllis garciai & 0.00 & 1.24 & 0.00 & 0.00 & 2.48 & 3.72 \\
\hline & Syllis gracilis & 0.00 & 0.00 & 2.48 & 0.00 & 1.24 & 11.16 \\
\hline & Tharyx killariensis & 126.49 & 2.48 & 0.00 & 1.24 & 2.48 & 1.24 \\
\hline & Thelepus setosus & 0.00 & 0.00 & 0.00 & 0.00 & 1.24 & 28.52 \\
\hline & Websterinereis glauca & 0.00 & 0.00 & 0.00 & 1.24 & 1.24 & 0.00 \\
\hline \multirow[t]{24}{*}{ Crustacea } & Anapagurus sp. & 0.04 & 0.00 & 0.00 & 0.00 & 0.00 & 0.00 \\
\hline & Athanas nitescens & 0.00 & 1.24 & 1.24 & 0.00 & 0.00 & 1.24 \\
\hline & Bathyporeia elegans & 0.00 & 0.00 & 0.00 & 7.44 & 0.00 & 0.00 \\
\hline & Bathyporeia guilliamsoniana & 34.72 & 0.00 & 0.00 & 0.00 & 0.00 & 0.00 \\
\hline & Bathyporeia nana & 0.00 & 0.00 & 0.00 & 1.24 & 0.00 & 0.00 \\
\hline & Bathyporeia pelagica & 1.24 & 0.00 & 0.00 & 4.96 & 0.00 & 0.00 \\
\hline & Bathyporeia pilosa & 0.00 & 0.00 & 0.00 & 2.48 & 0.00 & 0.00 \\
\hline & Bodotria pulchella & 0.00 & 0.00 & 0.00 & 0.00 & 1.24 & 0.00 \\
\hline & Bodotria scorpioides & 1.24 & 0.00 & 0.00 & 0.00 & 1.24 & 0.00 \\
\hline & Cancer pagurus & 0.00 & 0.00 & 2.48 & 0.00 & 0.00 & 1.24 \\
\hline & Carcinus maenas & 2.48 & 0.00 & 29.76 & 7.44 & 1.24 & 89.28 \\
\hline & Cleantis prismatica & 0.00 & 1.24 & 0.00 & 4.96 & 0.00 & 0.00 \\
\hline & Corophium arenarium & 3.72 & 0.00 & 18.60 & 0.00 & 0.00 & 29.76 \\
\hline & Corophium volutator & 0.00 & 0.00 & 64.48 & 0.00 & 0.00 & 403.02 \\
\hline & Crangon crangon & 0.08 & 0.00 & 0.00 & 0.00 & 0.00 & 0.00 \\
\hline & Cumopsis goodsir & 1.24 & 0.00 & 0.00 & 62.00 & 1.24 & 0.00 \\
\hline & Diogenes pugilator & 0.11 & 0.00 & 0.00 & 0.11 & 0.00 & 0.04 \\
\hline & Eocuma dollfusi & 6.20 & 0.00 & 0.00 & 6.20 & 0.00 & 1.24 \\
\hline & Ericthonius punctatus & 0.00 & 0.00 & 0.00 & 0.00 & 0.00 & 2.48 \\
\hline & Eurydice pulchra & 0.00 & 0.00 & 0.00 & 2.48 & 0.00 & 0.00 \\
\hline & Gammaropsis nitida & 0.00 & 0.00 & 4.96 & 0.00 & 0.00 & 2.48 \\
\hline & Gnathia maxillaris & 0.00 & 0.00 & 9.92 & 0.00 & 0.00 & 90.52 \\
\hline & Hemigrapsus sp. & 0.00 & 1.24 & 1.24 & 0.00 & 0.00 & 0.00 \\
\hline & Jaera (Jaera) albifrons & 1.24 & 0.00 & 0.00 & 1.24 & 0.00 & 0.00 \\
\hline
\end{tabular}




\begin{tabular}{|c|c|c|c|c|c|c|c|}
\hline & Jassa ocia & 0.00 & 0.00 & 26.04 & 0.00 & 1.24 & 60.76 \\
\hline & Lekanesphaera levii & 8.68 & 13.64 & 171.13 & 12.40 & 47.12 & 358.38 \\
\hline & Lekanesphaera rugicauda & 3.72 & 3.72 & 79.36 & 9.92 & 9.92 & 49.60 \\
\hline & Leptocheirus sp. & 0.00 & 0.00 & 1.24 & 0.00 & 0.00 & 0.00 \\
\hline & Liocarcinus holsatus & 0.00 & 0.00 & 0.00 & 0.12 & 0.00 & 0.00 \\
\hline & Melita palmata & 0.00 & 9.92 & 161.21 & 1.24 & 6.20 & 117.81 \\
\hline & Microdeutopus sp. & 0.00 & 0.00 & 1.24 & 0.00 & 0.00 & 0.00 \\
\hline & Nymphon brevirostre & 0.00 & 0.00 & 0.00 & 0.00 & 0.00 & 2.48 \\
\hline & Orchomene humilis & 0.00 & 0.00 & 0.00 & 1.24 & 0.00 & 0.00 \\
\hline & Phtisica marina & 0.00 & 0.00 & 0.00 & 1.24 & 0.00 & 0.00 \\
\hline & Porcellana platycheles & 0.00 & 2.48 & 711.80 & 0.00 & 1.24 & 2679.79 \\
\hline & Portumnus latipes & 1.24 & 0.00 & 0.00 & 0.31 & 0.00 & 0.00 \\
\hline & Pseudocuma (Pseudocuma) longicorne & 3.72 & 0.00 & 0.00 & 0.00 & 0.00 & 0.00 \\
\hline & Pseudomystides limbata & 0.00 & 0.00 & 4.96 & 0.00 & 0.00 & 0.00 \\
\hline & Siphonoecetes (Centraloecetes) kroyeranus & 1.24 & 0.00 & 0.00 & 11.16 & 0.00 & 0.00 \\
\hline & Thia scutellata & 0.12 & 0.00 & 0.00 & 0.00 & 0.00 & 0.00 \\
\hline & Tryphosites longipes & 0.00 & 0.00 & 0.00 & 1.24 & 0.00 & 0.00 \\
\hline & Urothoe brevicornis & 2.48 & 0.00 & 0.00 & 2.48 & 0.00 & 0.00 \\
\hline & Urothoe elegans & 0.00 & 0.00 & 0.00 & 1.24 & 0.00 & 0.00 \\
\hline & Urothoe poseidonis & 3.72 & 0.00 & 0.00 & 12.40 & 0.00 & 1.24 \\
\hline & Urothoe pulchella & 23.56 & 0.00 & 0.00 & 24.80 & 0.00 & 0.00 \\
\hline & Urothoe sp. & 2.48 & 0.00 & 0.00 & 0.00 & 0.00 & 0.00 \\
\hline Mollusca & Abra alba & 0.19 & 0.06 & 0.00 & 1.26 & 0.07 & 0.00 \\
\hline & Acanthochitona crinita & 0.00 & 0.00 & 4.96 & 0.00 & 0.00 & 0.00 \\
\hline & Aeolidia papillosa & 0.00 & 0.00 & 1.24 & 0.00 & 0.00 & 0.00 \\
\hline & Buccinum undatum & 0.00 & 0.00 & 1.24 & 0.00 & 0.00 & 0.00 \\
\hline & Cerastoderma edule & 70.95 & 0.12 & 0.11 & 18.39 & 0.20 & 0.06 \\
\hline & Crepidula fornicata & 0.64 & 25.11 & 26.76 & 0.00 & 15.54 & 7.11 \\
\hline & Gibbula cineraria & 0.00 & 0.00 & 0.23 & 0.00 & 0.00 & 0.12 \\
\hline & Gibbula umbilicalis & 0.00 & 0.15 & 26.02 & 0.00 & 0.00 & 39.53 \\
\hline & Lacuna pallidula & 0.00 & 0.00 & 0.00 & 0.00 & 0.00 & 1.24 \\
\hline
\end{tabular}




\begin{tabular}{|c|c|c|c|c|c|c|c|}
\hline & Limecola balthica & 89.00 & 0.12 & 0.03 & 187.04 & 3.97 & 0.00 \\
\hline & Littorina littorea & 0.00 & 0.00 & 3.16 & 0.00 & 0.00 & 1.40 \\
\hline & Littorina saxatilis & 0.00 & 0.00 & 0.04 & 0.00 & 0.00 & 0.00 \\
\hline & Macomangulus tenuis & 0.27 & 0.00 & 0.00 & 0.52 & 0.03 & 0.00 \\
\hline & Magallana gigas & 0.00 & 0.00 & 17.60 & 0.00 & 0.12 & 23.31 \\
\hline & Modiolula phaseolina & 0.00 & 0.00 & 0.00 & 0.00 & 0.00 & 21.08 \\
\hline & Modiolus sp. & 0.00 & 0.00 & 0.00 & 0.00 & 0.00 & 14.88 \\
\hline & Mytilus cf. galloprovincialis & 1.24 & 0.31 & 5.13 & 0.76 & 0.20 & 10.91 \\
\hline & Nucella lapillus & 0.00 & 0.04 & 6.21 & 0.00 & 0.00 & 8.10 \\
\hline & Ocenebra erinaceus & 0.00 & 0.03 & 0.52 & 0.00 & 0.08 & 0.25 \\
\hline & Ostrea edulis & 0.00 & 0.00 & 0.04 & 0.00 & 0.00 & 0.04 \\
\hline & Phorcus lineatus & 0.00 & 0.00 & 0.00 & 0.00 & 0.00 & 0.04 \\
\hline & Polititapes aureus & 0.00 & 0.00 & 2.48 & 0.00 & 0.00 & 0.00 \\
\hline & Polititapes rhomboides & 0.00 & 0.04 & 0.07 & 0.00 & 0.00 & 0.00 \\
\hline & Ruditapes decussatus & 0.00 & 0.04 & 0.03 & 0.00 & 0.11 & 0.03 \\
\hline & Ruditapes philippinarum & 0.24 & 0.39 & 0.25 & 0.28 & 0.99 & 0.10 \\
\hline & Scrobicularia plana & 0.00 & 0.00 & 0.00 & 1.24 & 0.00 & 0.00 \\
\hline & Spisula elliptica & 0.00 & 0.00 & 0.00 & 0.00 & 2.48 & 0.00 \\
\hline & Spisula solida & 0.04 & 0.41 & 0.00 & 0.91 & 0.16 & 0.00 \\
\hline & Tritia reticulata & 6.73 & 0.08 & 0.24 & 3.61 & 0.35 & 0.10 \\
\hline & Venerupis corrugata & 0.12 & 0.54 & 0.81 & 0.16 & 0.23 & 1.62 \\
\hline & Venus verrucosa & 0.00 & 0.00 & 0.00 & 0.00 & 0.04 & 0.00 \\
\hline Ascidiacea & Microcosmus claudicans & 0.00 & 0.00 & 0.00 & 0.00 & 0.00 & 9.92 \\
\hline & Molgula sp. & 0.00 & 0.00 & 0.00 & 0.00 & 1.24 & 7.44 \\
\hline & Phallusia mammillata & 0.00 & 0.00 & 0.00 & 0.00 & 0.00 & 1.24 \\
\hline & Polycarpa fibrosa & 0.00 & 0.00 & 0.00 & 0.00 & 0.00 & 14.88 \\
\hline & Polyclinum aurantium & 0.00 & 0.00 & 11.16 & 0.00 & 0.00 & 0.00 \\
\hline & Pyura microcosmus & 0.00 & 0.00 & 7.44 & 0.00 & 0.00 & 0.00 \\
\hline & Styela clava & 0.00 & 0.00 & 7.44 & 0.00 & 0.00 & 16.12 \\
\hline Anthozoa & Actinia equina & 0.00 & 0.00 & 0.00 & 0.00 & 0.03 & 0.04 \\
\hline & Anemona sp. & 0.00 & 0.00 & 0.00 & 0.00 & 0.00 & 1.24 \\
\hline
\end{tabular}




\begin{tabular}{|c|c|c|c|c|c|c|c|}
\hline & Cereus pedunculatus & 2.48 & 9.92 & 64.48 & 0.00 & 2.48 & 58.28 \\
\hline & Urticina felina & 0.00 & 0.00 & 0.00 & 0.00 & 0.00 & 0.04 \\
\hline \multirow[t]{4}{*}{ Pycnogonida } & Achelia echinata & 0.00 & 1.24 & 54.56 & 0.00 & 4.96 & 1311.99 \\
\hline & Achelia laevis & 0.00 & 0.00 & 8.68 & 0.00 & 1.24 & 261.65 \\
\hline & Achelia simplex & 0.00 & 1.24 & 95.49 & 0.00 & 2.48 & 962.29 \\
\hline & Anoplodactylus virescens & 0.00 & 0.00 & 0.00 & 0.00 & 0.00 & 17.36 \\
\hline \multirow[t]{4}{*}{ Sipuncula } & Golfingia (Golfingia) elongata & 0.00 & 3.72 & 6.20 & 0.00 & 0.00 & 57.04 \\
\hline & Golfingia (Golfingia) vulgaris vulgaris & 0.00 & 24.80 & 192.21 & 0.00 & 8.68 & 130.21 \\
\hline & Nephasoma (Nephasoma) minutum & 0.00 & 22.32 & 62.00 & 0.00 & 16.12 & 626.23 \\
\hline & Phascolion (Phascolion) strombus strombus & 0.00 & 1.24 & 0.00 & 0.00 & 0.00 & 0.00 \\
\hline \multirow[t]{2}{*}{ Echinodermata } & Acrocnida spatulispina & 1.24 & 0.00 & 0.00 & 1.24 & 0.00 & 0.00 \\
\hline & Amphipholis squamata & 0.00 & 2.48 & 0.00 & 0.00 & 2.48 & 49.60 \\
\hline \multirow[t]{3}{*}{ Other } & Nematoda & 1.24 & 6.20 & 9.92 & 1.24 & 102.93 & 2368.53 \\
\hline & Nemertea & 0.00 & 11.16 & 69.44 & 6.20 & 47.12 & 184.77 \\
\hline & Oligochaeta & 0.00 & 0.00 & 1.24 & 0.00 & 33.48 & 38.44 \\
\hline \multirow[t]{2}{*}{ Insecta } & Axelsonia littoralis & 0.00 & 0.00 & 79.36 & 0.00 & 0.00 & 13.64 \\
\hline & Hydrogamasus sp. & 0.00 & 0.00 & 14.88 & 0.00 & 0.00 & 8.68 \\
\hline Vertebrata & Lipophrys pholis & 0.00 & 0.00 & 0.04 & 0.00 & 0.00 & 0.12 \\
\hline
\end{tabular}

